\title{
ANALISIS KEBIJAKAN MONETER DALAM MODEL MAKROEKONOMETRIK STRUKTURAL JANGKA PANJANG: STRUCTURAL COINTEGRATING VECTOR AUTOREGRESSION
}

\author{
Solikin
}

\begin{abstract}
A b s t r a c t
The paper analyzes the monetary policy behavior by developing a long-run structural macroeconometric model; the Structural Cointegrating Vector Autoregression. The model is empirically proposed by Garratt et. al. (1998 and 1999) and adopted to suit the indonesian case.

The result shows that the model perform well in explaining the monetary policy behavior in Indonesia. However, due to the limitation of data, and a re-orientation of monetary policy, we should carefully examine and interpreting the magnitude of parameters used on the model.
\end{abstract}

Keywords: Kebijakan Moneter di Indonesia, Model Makro Struktural Jangka Panjang, Structural Cointegration Vector Autoregression (VAR).

JEL Classification: C32, C51, E52, E58

1 Peneliti Ekonomi di Bank Indonesia dan pengajar tamu pada beberapa universitas di tanah air. Alamat: solikin@bi.go.id 


\section{PENDAHULUAN}

Analisis kebijakan moneter pada umumnya memfokuskan pada dua cakupan isu utama yang saling berkaitan. Pertama menyangkut permodelan dan pemilihan variabel kebijakan moneter, serta kedua berkaitan dengan kebijakan moneter dalam perekonomian. Beberapa pendekatan dikembangkan untuk menaksir keberadaan pengaruh uang dan kebijakan moneter terhadap kegiatan ekonomi riil. Dalam kaitan ini, alat dan metodologi yang digunakan dalam menaksir pengaruh uang dan kebijakan moneter telah mengalami evolusi dari waktu ke waktu, sebagai konsekuensi dari perkembangan teknik ekonometri time-series, maupun perubahan penekanan pada model teoritis yang digunakan. Dua tujuan utama dari pengujian tersebut adalah, selain untuk membuktikan apakah perubahan kebijakan moneter mempengaruhi fluktuasi ekonomi, juga untuk mencari pembenaran dan konsistensi dari beberapa teori yang telah dikembangkan terhadap fakta empiris. Dari beberapa studi yang telah dilakukan, beberapa yang sangat berperan dalam literatur ekonomi moneter dipioniri oleh studi Friedman and Schwartz (1963) dan Sims (1972, 1980, 1992).

Studi Friedman and Schwartz, yang didasarkan pada data makro perekonomian Amerika Serikat dengan rentang waktu sekitar 100 tahun, bertumpu sepenuhnya pada ketepatan pergerakan (timing pattern) terkait dengan siklus pertumbuhan uang beredar dengan pertumbuhan ekonomi, yang mendukung hubungan kausalitas perkembangan uang beredar dengan fluktuasi output. Dari temuan tersebut, disimpulkan bahwa perkembangan data mendukung sepenuhnya bukti bahwa pertumbuhan jumlah uang beredar merupakan referensi positif (dengan lead yang panjang) dari siklus ekonomi. Dalam kaitan ini, pertumbuhan uang beredar yang semakin cepat akan diikuti oleh peningkatan output di atas trend-nya, sebaliknya, perlambatan pertumbuhan uang beredar akan diikuti oleh penurunan output. Lebih jauh, variasi dari perubahan uang beredar tersebut diikuti oleh variasi dari kebiatan ekonomi riil dengan pola lead yang panjang dan beragam. Kritik pada kesimpulan tersebut muncul, terkait dengan pandangan bahwa pembuktian berdasarkan pada ketepatan pergerakan dan korelasi sederhana tidak dapat menunjukkan kausalitas dari pengaruh uang yang sebenarnya. Hal ini mengingat pembandingan titik-titik referensi dari siklus kegiatan ekonomi cenderung dapat mengabaikan informasi yang terkandung dalam perilaku time-series dari variabel-variabel uang beredar, output, dan suku bunga, sehingga sulit untuk menaksir pengaruh kebijakan moneter terhadap perkembangan output yang sebenarnya. Bahkan, melalui studinya Tobin (1970) berpendapat bahwa korelasi antara uang dan output tersebut ada dasarnya merupakan hasil dari kausalitas terbalik (reverse causality), yaitu bahwa perkembangan output mempengaruhi perkembangan uang beredar. Sementara itu, King and Plosser (1984) menekankan keberadaan inside money, komponen uang beredar yang merepresentasikan liabilitas sektor perbankan, sebagai faktor 
utama dalam menjelaskan korelasi antara uang dan output. Lebih lanjut, disimpulkan bahwa korelasi antara uang (M1 dan M2) dan output timbul sebagai akibat dari adanya endogenous response sektor dari perbankan terhadap gejolak ekonomi yang tidak terkait dengan penerapan kebijakan moneter.

Upaya Friedman dan pengikut Monetarist lainnya dalam pencarian bukti empiris mengenai keterkaitan uang dan kegiatan ekonomi tidak hanya didasarkan pada pengembangan analisis grafis dan korelasi sederhana. Friedman and Meiselman (1963) mengembangkan pendekatan permodelan ekonometrik, yang selanjutnya dikembangkan dan dikenal dengan Model St. Louis, untuk menganalisis pengaruh kebijakan moneter atau fiskal terhadap penentuan pendapatan nominal. Walaupun ditemukan bukti empiris tentang pengaruh kebijakan moneter yang lebih signifikan dan stabil, dibandingkan dengan pengaruh kebijakan fiskal, terhadap perkembangan output nominal, spesifikasi pendekatan tersebut mendapatkan kritik, khusunya terkait dengan adanya endogenitas dari uang, yang selanjutnya dapat mempengaruhi konsistensi penaksiran yang dilakukan dengan hanya menggunakan prosedur regresi sederhana.

Permasalahan terkait dengan endogenitas uang tersebut diatasi melalui kontribusi penting dari Sims (1972) melalui pengembangan pendekatan Granger causality dari keberadaan uang dan pendapatan nominal. Hasil kajian awal Sims menyimpulkan bahwa perilaku masa lalu uang (M1 dan uang primer) membantu menjelaskan perilaku pendapatan nominal di masa mendatang. Studi lanjutan Sims (1980) dengan pendekatan vector autoregression (VAR), dimana digunakan indeks produksi sebagai pengukur output riil serta suku bunga nominal sebagai variabel lain yang berpengaruh dalam sistem menunjukkan bahwa peranan uang dalam menjelaskan variasi output mengalami penurunan yang besar. Dengan demikian, pendekatan tersebut sangat sensitif terhadap spesifikasi variabel mana yang sebaiknya diperhitungkan. Terkait dengan keberadaan trend pada perkembangan variabel time series, Eichenbaum and Singleton (1986) menunjukkan bahwa penggunaan spesifikasi first difference, menghasilkan kesimpulan tentang pengaruh uang yang kurang signifikan dibandingkan dengan pengaruh uang pada spesifikasi level. Berbeda dengan hasil kajian tersebut, Stock and Watson (1989) menunjukkan bahwa dengan perlakuan yang sistematis terhadap spesifikasi trend, disimpulkan bahwa perkembangan uang menjelaskan perkembangan output di masa mendatang.

Keberadaan pendekatan VAR dalam pencarian bukti empiris mengenai keterkaitan uang dan output semakin mendapatkan perhatian dengan dikembangkannya sistem permodelan VAR berskala lebih besar, tidak sekedar 'bivariat' atau 'trivariat'. Sims (1992), dengan memperhitungkan beberapa variabel dalam sistem yaitu indeks produksi, indeks harga konsumen, suku bunga jangka pendek sebagai pengukur pengaruh kebijakan, uang beredar, nilai tukar, dan indeks harga komoditas, menyimpulkan bahwa respons output riil terhadap 
perkembangan suku bunga sejalan di beberapa negara maju yang dikaji, yaitu bahwa kebijakan moneter mempengaruhi perkembangan output dengan pola 'hump-shaped".

Dengan latar belakang pemikiran dan silang pendapat yang telah disinggung di atas, penelitian ini ditujukan untuk menganalisis perilaku kebijakan moneter melalui pengembangan model makroekonometrik jangka panjang, yang dikenal dengan Structural Cointerating Vector Autoregression (VAR). Secara empiris, pendekatan yang dikembangkan oleh Garratt et al. (1998 dan 1999) ini akan mengacu pada konteks perekonomian Indonesia. Menyambung pendahuluan ini, bagian kedua akan mengeksplorasi metodologi dan kerangka permodelan teoritis. Selanjutnya, sebelum beberapa catatan penutup, akan disampaikan hasil penaksiran dan analisis model hipotetis yang telah diajukan.

\section{METODOLOGI DAN KERANGKA PERMODELAN TEORITIS}

\section{II.1 Karakteristik Model Structural Cointegrating VAR dalam Kerangka Permodelan Ekonomi Makro}

Pendekatan structural cointegrating VAR pada dasarnya mengacu pada pengembangan model makroekonometrik dengan landasan teoritis yang transparan, yang memberikan pemahaman akan keterkaitan perilaku yang mendasari bekerjanya suatu sistem ekonomi. Selain itu, pendekatan ini memiliki dinamika yang fleksibel yang selaras dengan perilaku data time series. Strategi permodelan dimulai dengan pernyataan eksplisit mengenai keterkaitan jangka panjang antar variabel di dalam sistem permodelan dengan mendasarkan pada landasan teori ekonomi makro. Keterkaitan tersebut kemudian ditransformasikan atau aproksimasi ke dalam bentuk persamaan log-linear, dimana gangguan (disturbances) yang ada mencerminkan adanya deviasi dari keterkaitan jangka panjang terhadap realisasinya, komponen dalam jangka pendek. Deviasi tersebut pada dasarnya mencerminkan suatu kejutan struktural jangka panjang (longrun structural shocks). Dalam rangka mengekspresikan keterkaitan tersebut dalam perilaku variabel-variabel yang observable, diturunkan kejutan struktural jangka panjang dalam bentuk yang direduksi (long-run reduced form shocks), sebagai suatu fungsi dari long-run structural shocks. Kemudian, long-run reduced form shocks tersebut digunakan untuk merumuskan persamaan kointegrasi VAR yang mencerminkan keterkaitan struktural jangka panjang sebagaimana solusi yang bersifat steady state.

Dibandingkan dengan permodelan unrestricted and structural VARs pada umumnya, pendekatan tersebut mempunyai keunggulan dengan adanya hubungan yang sangat jelas antara estimated residuals dengan structural shocks dari model ekonomi yang mendasarinya. Hubungan tersebut mengindikasikan restriksi yang sangat jelas yang dibutuhkan untuk 
mengidentifikasi pengaruh spesifik dari suatu pengenaan kejutan (inovations) pada model. Dalam hal restriksi tersebut tidak memungkinkan, pendekatan tersebut memungkinkan adanya Generalized Impulse Response analysis—disamping Orthogonalized Impulse Reseponse —, yang menjelaskan pengaruh shocks pada suatu persamaan terhadap semua variabel dalam dalam sistem permodelan, dengan tanpa memberikan interpretasi ekonometrik pada jenis shocks. ${ }^{2}$ Dengan demikian, analisis yang dihasilkan mempunyai karakteristik yang berarti dari suatu respons dinamis perekonomian terhadap suatu shocks yang diamati secara umum.

Selanjutnya, dibandingkan dengan dengan model ekonomi simultan dengan skala besar (simultaneous economic models - SEMs), pendekatan tersebut mempunyai keunggulan dimana model dikembangkan dan ditaksir sedemikian rupa sehingga menjamin suatu konsistensi dengan landasan teoritis yang mengacu pada karakteristik jangka panjang perekonomian makro. Dalam kaitan ini, kejelasan karakteristik jangka panjang juga penting dalam analisis impulse response dan prediksi, terutama dalam jangka menengah. Akan tetapi, masih terdapat suatu restriksi, dan secara teknis, dengan data time series yang ada, efektivitas pendekatan tersebut cukup efektif apabila dilibatkan 8-10 variabel secara simultan. Dengan demikian, apabila analisis dibatasi pada model cointegrating VAR, baik model tunggal atau dengan skala yang sangat kecil, maka banyak isu penting yang tidak dapat diamati.

Yang terakhir, dibandingkan dengan dynamic stochastic general equilibrium model (DSGE), pedekatan ini mempunyai keterkaitan yang erat dalam konteks keterkaitan jangka panjang. Dalam DSGE, keterkaitan jangka panjang diperoleh dengan mengabaikan expectational errors mengasumsikan bahwa model ekonomi adalah stasioner dan 'ergodic' pada variabel tertentu, seperti tingkat pertumbuhan ekonomi dan rasio modal terhadap pekerja efektif. Sementara itu, di sisi lain, model structural cointegrating VAR bekerja secara langsung dengan kondisi arbitrase yang dimodifikasi seperlunya, yang mengimplikasikan adanya keterkaitan intertemporal antara variabel harga dan perolehan aset dalam perekonomian secara keseluruhan. Perbedaan utamanya adalah pada perlakuan kedua pendekatan tersebut terhadap perubahan dinamis jangka pendek. Dalam kaitan ini, pendekatan intertemporal optimization bertumpu pada identifikasi yang tegas pada macroeconomic disturbances sebagai shocks pada selera dan teknologi, sebagaimana

2 Mengikuti jejak Sim (1980), analisis dinamis model VAR dilakukan dengan menerapkan 'orthogonalized' impulse response, dimana sebelum dilakukan analisis impulse response dan variance decompositions, perilaku shocks pada model VAR diortogonalisasi dengan menggunakan Cholesky decomposition. Pendekatan ini mengandung kelemahan karena sangat bergantung pada urutan variabel dalam sistem model VAR. Untuk mengatasi permasalahan tersebut, dengan mendasarkan pada kajian Koop et al. (1996), Pesaran and Shin (1997) mengajukan analisis 'generalized' impulse response, suatu pendekatan yang tidak memerlukan pengortogonalisaian shocks dan tidak terpengaruh oleh urutan variabel dalam sistem model VAR. Dalam kaitan ini, untuk untuk suatu matrik error variance yang non-diagonal, 'orthogonalized' dan 'generalized' impulse response memiliki kesamaan hanya pada kasus pengenaan impulse reseponse dari shocks pada persamaan pertama dalam sistem model VAR. 
dinyatakan dalam bentuk dinamika jangka pendek, pendekatan structural cointegrating VAR relatif netral terhadap fenomena tersebut.

\section{II.2 Pengembangan Model Hipotetis untuk Perekonomian Indonesia}

Dalam penelitian ini digunakan permodelan makro structural cointegrating VAR yang dikembangkan oleh Garratt et al (1998 dan 1999). Dalam kajiannya, Garratt et al. menetapkan dua versi model inti (core models) dengan lima keterkaitan keseimbangan jangka panjang. Selain persamaan "Output-Gap", keterkaitan Purchasing Power Parity, keterkaitan Interest Rate Parity, dan keterkaitan Money Market Equilibrium, versi pertama melibatkan juga keterkaitan Trade Balance, sementara tingkat harga ditaksir secara relatif terhadap harga minyak internasional. Sementara itu, versi kedua melibatkan Fisher Inflation Parity sebagai pengganti keterkaitan Trade Balance, namun tingkat harga tidak diukur dalam konsep relatif..

Dalam penelitian ini, beberapa modifikasi dilakukan dengan mempertimbangkan karakteristik perekonomian Indonesia dan perilaku variabel ekonomi yang mendasarinya. Pertama, penulis mengeluarkan persamaan Output-Gap dalam model inti. Sebagai suatu 'smallopen-developing' economy, Indonesia memiliki karakteristik struktural yang berbeda dengan negara lain, sehingga hal tersebut menyulitkan dalam menemukan keterkaitan 'Output-Gap' sebagimana disarankan oleh Garratt et al. (1998 and 1999). Permasalahan teknis juga akan muncul apabila dikaitkan dengan observasi pada periode kiris ekonomi, misalnya krisis ekonomi 1997. Walaupun tidak terdapat bukti empiris, penulis mengkategorikan negara-negara dalam kelompok emerging markets di Asia sebagai acuan kondisi bagi perkembangan perekonomian Indonesia. Dalam kaitan tersebut, dapat diamati bahwa negara-negara di Asia memiliki latar belakang fundamental ekonomi yang berbeda serta mengalami dampak krisis ekonomi yang berbeda pula. Hal tersebut menyebabkan terdapatnya perbedaaan kecepatan konvergensi kondisi ekonomi pada kondisi semula (sebelum krisis).

Kedua, penulis menggunakan tingkat harga dengan pemahaman yang berbeda, yaitu dengan memperlakukan tingkat harga domestik secara terpisah dengan tingkat harga internasional. Secara teknis, perlakuan ini terkait dengan transformasi variabel dalam bentuk I(1), sementara keberadaan tingkat harga domestik lebih bermakna dibandingkan dengan dalam interaksi antar variabel dalam sistem domestic-foreign price ratio atau perubahan harga (inflasi). Konsekuensi dari langkah tersebut adalah pengeluaran keterkaitan Fisher Interest Parity, yang melibatkan inflasi, dari model inti.

Ketiga, penulis mengajukan keterkaitan Employment Determination Equilibrium, yang mengetengahkan pada dasarnya "sintesa keseimbangan pasar input dan barang". 
Keberadaan persamaan tersebut selain untuk menangkap perilaku tingkat output dan kesempatan kerja, juga keterkaitan kedua variabel makro utama tersebut dengan suku bunga dan harga. Selain itu, walaupun terdapat keterkaitan erat antara perkembangan output dan kesempatan kerja, perilaku kedua variabel tersebut perlu diamati dalam konteks kerangka permodelan secara utuh, terutama apabila dikaitkan dengan penetapan kedua variabel sebagai sasaran akhir kebijakan (bersama inflasi.

Dengan berdasarkan strategi di atas, dari pengembangan model inti diharapkan selain didapatkan statistik yang lebih realistik secara teoritis dan empiris, juga dapat dikaji karakteristik keterkaitan jangka panjang yang sesuai dengan landasan teoritis ala model dinamis keseimbangan umum (dynamic general equilibrium models). Dengan demikian, empat persamaan keseimbangan jangka panjang yang dapat merepresentasikan keterkaitan antara variabel ekonomi makro utama, khususnya variabel sasaran operasional dan sasaran akhir kebijakan, adalah:

(i) Hubungan kesimbangan arbitrasi pasar barang (Purchasing Power Parity)

(ii) Sintesa Okun's Law dan hubungan keseimbangan pasar barang (Employment Determination Equilibrium)

(iii) Hubungan keseimbangan pasar uang (Money Market Equilibrium)

(iv) Hubungan paritas suku bunga (Interest Rate Parity)

Adapun penurunan masing-masing model teoritis yang mencerminkan hubungan jangka panjang tersebut dapat dijelaskan sebagai berikut.

\section{II.2.1 Purchasing Power Parity (PPP): "arbitrase pasar barang"}

Konsep PPP relationship didasarkan pada keberadaan arbitrase pasar barang, dan menangkap idea dasar bahwa harga sekumpulan barang-barang akan sama di negara yang berlainan apabila diukur dengan menggunakan mata uang yang dipakai secara umum (common currency). Disparitas informasi, biaya transportasi, dan pengaruh restriksi perdagangan dapat menyebabkan deviasi perilaku pada PPP dalam jangka pendek. Namun, apabila besar pengaruh tersebut konstan sepanjang waktu, maka harga-harga sekumpulan barang dalam comon currency di negara yang berlainan akan meningkat secara one-for-one dalam jangka panjang. Kondisi tersebut terungkap oleh relative PPP, yang secara umum diekspresikan sebagai (Obstfeld and Rogoff, 1996):

$$
P_{t+1}=E_{t+1} P_{t+1}^{*} \exp \left(\eta_{p p p, t+1}\right)
$$

, dimana $\mathrm{P}, \mathrm{P}^{*}$, dan $\mathrm{E}$ masing-masing adalah tingkat harga domestik, tingkat harga luar negeri (internasional), dan nilai tukar. 
Log-linierisasi kondisi tersebut adalah:

$\ln \left(P_{t+1}\right)=\ln \left(P_{t+1}^{*}\right)+\ln \left(E_{t+1}\right)+\eta_{p p p, t+1}$

\section{II.2.2 Employment Determination Equilibrium (EDE): "sintesa keseimbangan pasar input dan barang"}

Okun's law (Okun, 1962) merepresentasikan keterkaitan antara output dan pengangguran. Secara teorits, Okun's law merupakan pengait (link) antara penawaran agregat dengan Kurva Phillips. Dengan kondisi tersebut, pengamatan keberadaan kurva Phillips dan Okun's law mempunyai keselarasan (Debelle and Laxton, 1997; Laxton et al., 1999; Lee, 2000). Versi umum dari Okun's law adalah persamaan kesenjangan, yaitu:

$$
y_{t}-y^{*}=\alpha\left(u_{t}-u_{t}^{*}\right)+e_{t}
$$

, dimana $\alpha<0$. Persamaan tersebut pada dasarnya menunjukkan keterkaitan dinamis jangka pendek. Prachowny (1993) menunjukkan bahwa secara formal keterkaitan di atas dapat diturunkan dari fungsi produksi:

$$
y_{t}=\alpha\left(k_{t}+c_{t}\right)+\beta\left[\gamma\left(l_{t}-u_{t}\right)+\delta h_{t}\right]+\tau_{t}+\varepsilon_{t}
$$

, dimana y adalah output riil, $k$ adalah input modal, c adalah capital utilization, I adalah labor force, $u$ adalah tingkat pengangguran, $h$ adalah jumlah jam kerja, t adalah technological progress, dan e adalah error term.

Persamaan tersebut pada dasarnya merupakan keterkaitan Okun's law dalam keseimbangan jangka panjang antara output riil dan pengangguran $(\beta>0)$, ceteris paribus keberadaan variabel-variabel lain. Mengingat output riil dan pengangguran merupakan variabel yang cenderung bersifat non-stasioner, Attfield and Silverstone $(1997,1998)$ melakukan pengujian dan menunjukkan bahwa output riil dan pengangguran berkointegrasi. Adapun persamaan jangka panjang antara output riil dan pengangguran (dengan penekanan hasil uji bahwa output riil lebih bersifat weakly exogenous) adalah:

$$
\ln u_{t}=\beta_{0}+\beta_{1} \ln y_{t}+\beta_{2} t+\varepsilon_{t}
$$

, dimana $\beta_{1}<0$ dan time trend $(t)$ mengakomodir pertumbuhan linier jangka panjang yang tidak dapat dijelaskan oleh model.

Selanjutnya, dengan memperhitungkan perilaku $y_{t}$ dalam keterkaitan keseimbangan Kurva IS berdasarkan spesifikasi optimal (expectational version of the IS function) yang dikembangkan oleh McCallum and Nelson (1997): 


$$
\ln y_{t}=b_{0}+b_{1} r_{t}+E_{t} \ln y_{t+1}+v_{t}
$$

, maka diperoleh spesifikasi keseimbangan jangka panjang sintesa Okun's law dan keseimbangan pasar barang sebagai berikut:

$$
\begin{aligned}
\ln u_{t} & =\beta_{0}+\beta_{1}\left(b_{0}+b_{1} r_{t}+\ln y_{t+1}+\eta_{t+1}+v_{t}\right)+\beta_{2} t+\varepsilon_{t} \\
& =\gamma_{0}+\gamma_{1} r_{t}+\gamma_{2} \ln y_{t+1}+\gamma_{3} t+\eta_{y u, t+1}
\end{aligned}
$$

, dimana $r_{t}$ adalah suku bunga riil, $\gamma_{0}=\left(\beta_{o}+\beta_{1} b_{0}\right), \gamma_{1}=\beta_{1} b_{1}, \gamma_{2}=\beta_{1}, \gamma_{3}=\beta_{3}$, dan $\eta_{y u, t+1}=\left(\eta_{t+1}+\right.$ $\left.v_{t}+\varepsilon_{t}\right)$

Pola hubungan keseimbangan dalam persamaan tersebut $\left(\gamma_{1}>0, \gamma_{2}<0\right)$ pada dasarnya selaras dengan perilaku persamaan "pengangguran" yang dikembangkan oleh Sim (1986) dalam permodelan structural $V A R$, yaitu:

$$
u_{t}=\gamma_{1} i_{t}+\gamma_{2} \ln p_{t}+\gamma_{3} \ln y_{t}+\ln f i_{t}+\eta_{t}
$$

, dimana $i_{t}$ adalah suku bunga nominal jangka panjang, $f i_{t}$ adalah investasi tetap riil.

\section{II.2.3 Money Market Equilibrium (MME): "keseimbangan pasar uang dengan kendala solvensi jangka panjang"}

Keterkaitan keseimbangan di pasar uang merepresentasikan fungsi permintaan asset, dalam hal ini high-powered money, dengan konstrain solvensi jangka panjang. Selaras dengan Portfolio Balance Approach (Branson, 1977), kondisi keseimbangan jangka panjang dirumuskan sebagai:

$$
\frac{\widetilde{H}_{t+1}}{\widetilde{Y}_{t}}=\mu F\left(Y_{t}, R_{t}, t\right) \exp \left(\eta_{y, t+1}+\eta_{h, t+1}\right)
$$

, dimana $\frac{\widetilde{H}_{t+1}}{\widetilde{Y}_{t}}$ adalah rasio high-powered money terhadap pendapatan nominal. Sementara itu, determinan dari persamaan (IV.9) adalah output riil, rate of return pemegangan aset finansial, dan unsur trend.

Log-linierisasi persamaan tersebut menghasilkan:

$$
\ln (\tilde{h} / \tilde{y})=\alpha+\gamma_{1} \ln y_{t}+\gamma_{2} \ln R_{t}+\gamma_{3} t+\eta_{y h, t+1}
$$

Hubungan keseimbangan dalam persamaan tersebut pada dasarnya selaras dengan perilaku keseimbangan real money balances dalam Kurva LM pada versi umumnya (McCallum and Nelson, 1997), yaitu:

$$
\ln M_{t}-\ln p_{t}=\alpha+\gamma_{1} \ln y_{t}+\gamma_{2} \ln R_{t}+\eta_{t}
$$

, dimana $\gamma_{1}>0, \gamma_{2}<0$. 


\section{II.2.4 Interest Rate Parity (IRP): "arbitrase pasar uang"}

Kondisi paritas suku bunga mengacu pada pada kondisi tertentu dari arbitrase pasar uang berdasarkan hubungan uncovered interest parity (UIP), yang mencerminkan kondisi keseimbangan proses arbitrase antara pemegangan surat berharga domestik dan luar negeri. Dalam kaitan ini, setiap perbedaan suku bunga di antara negara-negara terkait ( $R$ dan $R^{*}$ ) akan di-offset oleh ekspektasi perubahan nilai tukar (E). Namun, adanya biaya transaksi, premi risiko, dan pengaruh spekulatif menyebabkan penyimpangan pada hubungan uncovered interest parity dalam jangka pendek. Dengan demikian, kondisi arbitrase pasar uang dijabarkan melaui interest rate parity, yang diformulasikan sebagai (Obstfeld and Rogoff, 1996):

$$
\begin{aligned}
\left(1+R_{t}\right) & =\left(1+R_{t}^{*}\right)\left(1+\frac{E_{t+1}^{e}-E_{t}}{E_{t}}\right) \exp \left(\eta_{u i p, t+1}\right) \\
& =\left(1+R_{t}^{*}\right)\left(\frac{E_{t+1}^{e}}{E_{t+1}}\right)\left(1+\frac{\Delta E_{t+1}}{E_{t}}\right) \exp \left(\eta_{u i p, t+1}\right)
\end{aligned}
$$

Dengan kecilnya kemungkinan untuk melakukan obeservasi langsung pada ekspektasi nilai tukar, maka didefinisikan hubungan permodelan jangka panjang, yaitu:

$$
E_{t+1}^{e}=E_{t+1} \exp \left(\eta_{e, t+1}^{e}\right)
$$

Substitusi (4b) ke (4a) dan dilanjutkan dengan log-linierisasi persamaan tersebut menghasilkan:

$$
\ln \left(1+R_{t}\right)=\ln \left(1+R_{t}^{*}\right)+\eta_{\Delta e, t+1}+\eta_{u i p, t+1}+\eta_{e, t+1}^{e}
$$

\section{II.2.5 Interaksi dinamis jangka pendek antar variabel}

Bangun model stuktural, selain mengacu pada analis keseimbangan antar-variabel dalam persamaan jangka panjang, juga memperhitungkan pengaruh dinamis jangka pendek antar variabel dalam sistem secara keseluruhan. Selain beberapa variabel makro utama yang telah dicakup sebelumnya, yaitu harga, nilai tukar, suku bunga, besaran moneter, tingkat output, dan tingkat pengangguran, sistem permodelan juga memperhitungkan perkembangan variabel indeks harga saham, yang menangkap pengaruh yang signifikan dari dinamika perkembangan pasar modal terhadap perekonomian makro, khususnya dalam satu dasawarsa terakhir.

Sebagaimana bangun model umumnya yang memperhitungkan mekanisme "error corection" dalam sistem, maka sistem permodelan struktural cointegrating VAR ini juga menekankan adanya mekanisme penyesuaian dinamis jangka pendek dari keterkaitan antar variabel dengan mengacu pada kondisi keseimbangan jangka panjang dalam sistem. Dengan demikian, bangun sistem permodelan pada dasarnya diarahkan untuk dapat menangkap 
keterkaitan jangka panjang antar-variabel yang konsisten dengan landasan teori (theory consistent) dan mempunyai interpretasi ekonomi yang jelas, dengan interaksi dinamis jangka pendek antar variabel yang secara fleksibel dapat ditaksir dengan menggunakan kerangka model VAR.

Berdasarkan paparan landasan teoritis beberapa model keseimbangan jangka panjang di atas, maka formulasi dari "core model" keseimbangan jangka panjang untuk tujuan pengujian empiris yang diajukan adalah: ${ }^{3}$

$$
\begin{array}{ll}
p_{t}-p_{t}^{*}-e_{t} & =a_{10}+a_{11} t+\xi_{1, t+1} \\
n_{t} & =a_{20}+a_{21} t+\beta_{22}\left(r_{t}-p_{t}\right)+\beta_{21} y_{t}+\xi_{2, t+1} \\
m_{t}-p_{t} & =a_{30}+a_{31} t+\beta_{33} r_{t}+\beta_{35} y_{t}+\xi_{3, t+1} \\
r_{t}-r^{*}{ }_{t} & =a_{40}+\xi_{4, t+1}
\end{array}
$$

Dari bangun model di atas, vektor error term (reduced form) dapat dituliskan sebagai:

$$
\begin{aligned}
& \xi_{1, t+1}=p_{t}-p_{t}^{*}-e_{t}-a_{10}-a_{11} t \\
& \xi_{2, t+1}=n_{t}-\beta_{22}\left(r_{t}-p_{t}\right)-\beta_{21} y_{t}-a_{20}-a_{21} t \\
& \xi_{3, t+1}=m_{t}-p_{t}-\beta_{33} r_{t}-\beta_{35} y_{t}-a_{30}-a_{31} t \\
& \xi_{4, t+1}=r_{t}-r_{t}^{*}{ }_{t}-a_{40}
\end{aligned}
$$

atau:

$$
\xi_{t}=b^{\prime} z_{t-1}-\left(a_{0}-a_{1}\right)-a_{1} t,
$$

$$
\begin{aligned}
& \text { dimana: } \mathbf{z}_{\mathrm{t}}=\left(r_{t}, p_{t}, y_{t}, n_{t}, p_{t}^{*}, e_{t}, m_{t}, s_{t}, r_{t}^{*}\right) \\
& r_{t}: \text { suku bunga nominal } \\
& p_{t}: \text { indeks harga barang domestik } \\
& y_{t}: \text { output riil } \\
& n_{t}: \text { kesempatan (lapangan) kerja } \\
& p_{t}^{*}: \text { indeks harga barang internasional } \\
& e_{t}: \text { nilai tukar mata uang domestik terhadap mata uang internasional (US\$) } \\
& m_{t}: \text { besaran moneter nominal } \\
& s_{t}: \text { indeks harga saham } \\
& r_{t}^{*}: \text { suku bunga internasional }
\end{aligned}
$$

3 Secara intuitif, pengakomodiran variabel trend ditujukkan untuk mengantisipasi (kemungkinan) adanya kecenderungan perilaku jangka panjang keterkaitan variabel yang tidak dapat dijelaskan oleh model. Secara metodologis, validitas dari langkah tersebut umumnya diukur melalui signifikasi parameter dan/atau pengujian identifikasi (over or under identified) sistem permodelan. 
$\mathrm{a}_{0}=\left(\boldsymbol{a}_{10}, \boldsymbol{a}_{20}, \boldsymbol{a}_{30}, \boldsymbol{a}_{40}\right)^{\prime}, \mathrm{a}_{1}=\left(\boldsymbol{a}_{11}, \boldsymbol{a}_{21}, \boldsymbol{a}_{31}\right)^{\prime}, \xi_{\mathrm{t}}=\left(\xi_{1 t}, \xi_{2 t}, \xi_{3 t}, \xi_{4 t}\right)^{\prime}$,

dan

$$
\boldsymbol{\beta}^{\prime}=\left(\begin{array}{ccccccccc}
0 & 1 & 0 & 0 & -1 & -1 & 0 & 0 & 0 \\
-\beta_{22} & \beta_{22} & -\beta_{21} & 1 & 0 & 0 & 0 & 0 & 0 \\
-\beta_{33} & -1 & -\beta_{35} & 0 & 0 & 0 & 1 & 0 & 0 \\
1 & 0 & 0 & 0 & 0 & 0 & 0 & 0 & -1
\end{array}\right)
$$

Dalam permodelan dinamis jangka pendek, penyimpangan terhadap hubungan jangka panjang, $\xi_{\mathrm{t}}$, dapat diaproksimasi dengan menggunakan fungsi linier dari sejumlah (finite) perubahan dari nilai masa lalu dari $\mathbf{z}_{\mathrm{t}-1}$. Dengan demikian, strategi permodelan yang digunakan adalah memperhitungkan $\xi_{\mathrm{t}}$ dalam error correction model:

$$
\Delta \mathrm{z}_{\mathrm{t}}=\mathrm{b}-\boldsymbol{\alpha} \boldsymbol{\xi}_{\mathrm{t}}+\sum_{i-1}^{\mathrm{s}-1} \boldsymbol{\Gamma}_{\mathrm{i}} \boldsymbol{\Delta} \mathrm{z}_{\mathrm{t}-\mathrm{i}}+\mathrm{u}_{\mathrm{t}}
$$

dimana $\mathbf{b}$ adalah vektor $4 \times 1$ dari intercept, a adalah matrik 4x4 dari koefisien error correction (juga dikenal sebagai the loading coefficient matrix), $\left\{\Gamma_{\mathrm{i}}, \mathrm{i}=1, \ldots, \mathrm{s}-1\right\}$ adalah matrik $4 \times 9$ dari koefisien jangka pendek, $\mathbf{u}_{\mathrm{t}}$ adalah vektor $9 \times 1$ dari disturbances yang diasumsikan $\operatorname{IID}(0, \Sigma)$, dengan $\Sigma=\left(\sigma_{\mathrm{ij}}\right)$ adalah matrik positive definite. Dengan menggunakan persamaan (IV.18), didapatkan:

$$
\Delta \mathrm{z}_{\mathrm{t}}=\mathbf{c}+\boldsymbol{\alpha}\left(\mathbf{a}_{1} \mathrm{t}-\boldsymbol{\beta}^{\prime} \mathbf{z}_{\mathrm{t}-1}\right)+\sum_{i-1}^{s-1} \boldsymbol{\Gamma}_{\mathrm{i}} \Delta \mathrm{z}_{\mathrm{t}-\mathrm{i}}+\mathrm{u}_{\mathrm{t}}
$$

, dimana $\mathbf{c}=\mathbf{b}+\boldsymbol{\alpha}\left(\mathbf{a}_{1}-\mathbf{a}_{0}\right)$ dan $\boldsymbol{\xi}_{\mathrm{t}}=\boldsymbol{\beta}, \mathrm{z}_{\mathrm{t}-1}$ adalah error correction terms. Dilihat dari konstruksinya, spesifikasi permodelan di atas mengandung prediksi jangka panjang dari teori ekonomi, berbeda dengan pendekatan yang didasarkan pada unrestricted VAR yang mengasumsikan adanya sifat keterkaitan jangka panjang secara "tersamar".

\section{II.2.6 Pengidentifikasian respons dan shocks kebijakan moneter}

Strategi untuk asumsi pengidentifikasian shocks kebijakan moneter dalam penelitian ini merupakan feedback rule or reaction function dari otoritas moneter, yaitu suatu rule yang mengkaitkan respons kebijakan otoritas moneter dengan kondisi perekonomian. Dengan demikian, asumsi yang diperlukan (necessary assumptions) umumnya meliputi asumsi bentuk fungsional, asumsi mengenai variabel yang diperhitungkan oleh otoritas moneter dalam penetapan instrumen dan kerangka oparasional, dan asumsi mengenai apa instrumen atau sasaran operasional itu sendiri. Selain itu, asumsi yang harus diacu adalah asumsi mengenai 
sifat dari keterkaitan antara kebijakan moneter dengan variabel-variabel dalam feedback rule. Berkaitan dengan hal tersebut, banyak pendapat yang menyatakan bahwa fraksi yang cukup besar dari variasi langkah otoritas moneter merefleksikan respon yang sistematis terhadap kondisi ekonomi. Dalam praktek ditemukan fakta bahwa tidak semua variasi dari langkah otoritas moneter merefleksikan respon yang sistematis terhadap kondisi ekonomi. Dalam kaitan ini, variasi yang tidak dapat diperhitungkan tersebut secara formal dikenal sebagai shocks kebijakan moneter.

Sebagaimana pendekatan-pendekatan yang lazim digunakan, misalnya oleh Sims (1992), Bernanke et al. (1997), dan Garratt et al. (1998), diasumsikan bahwa shocks kebijakan moneter ditaksir sebagai komponen yang tidak sistematis (non-systematic component) dari perubahan perilaku sasaran operasional atau instrumen kebijakan. Dengan demikian, komponen yang sitematis (systematic component) dari kebijakan moneter dapat diturunkan sebagai solusi problem optimisasi otoritas moneter. Dalam penelitian ini akan digunakan beberapa indikator sasaran operasional kebijakan moneter, yaitu suku bunga (price-based approach). Selain itu, penting pula untuk melihat peranan variabel operasional lain, yaitu nilai tukar dan uang primer (quantity-based approach), walaupun terdapat kecenderungan bagi otoritas moneter untuk meninggalkan penggunaanya.

Analogi dengan pendekatan Garratt et al, problem optimisasi yang ditetapkan adalah minimisasi fungsi kerugian (losss function) otoritas moneter yang memperhitungkan keberadaan sasaran akhir dan sasaran operasional atau instrumen kebijakan moneter secara lebih umum, yaitu:

$$
\operatorname{Min}_{\mathrm{rt}}\left\{\mathrm{E}\left[\boldsymbol{C}\left(\mathbf{w}_{\mathrm{t}}, \mathrm{r}_{\mathrm{t}}\right) \mid \Psi_{t-1}\right]\right\}
$$

, dimana $\Psi_{\mathrm{t}-1}$ adalah information set dari otoritas moneter pada akhir periode t-1 dan $\boldsymbol{C}\left(\mathbf{w}_{\mathbf{t}}, \mathbf{r}\right)$ adalah fungsi kerugian kuadratik:

$$
\boldsymbol{C}\left(\mathbf{w}_{\mathrm{t}}, \mathrm{r}_{\mathrm{t}}\right)=1 /{ }_{2}\left\{\left(\mathbf{w}_{\mathrm{t}}-\mathbf{w}_{\mathrm{t}}^{\mathrm{t}}\right)^{c} \mathbf{Q}\left(\mathbf{w}_{\mathrm{t}}-\mathbf{w}_{\mathrm{t}}^{\mathrm{t}}\right)+\theta\left(\mathrm{r}_{\mathrm{t}}-\mathrm{r}_{\mathrm{t}-1}\right)^{2}\right\}
$$

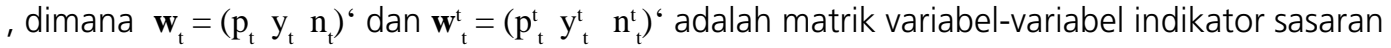
akhir (target variables), dan masing-masing tingkat yang diharapkan (desired values), yang diasumsikan mempunyai derajad itegrasi satu, I(1). Fungsi tujuan tersebut dapat pula dituliskan dalam bentuk variabel stasioner, yaitu:

$$
\boldsymbol{C}\left(\mathbf{w}_{\mathrm{t}}, \mathbf{r}_{\mathrm{t}}\right)=1 / 2\left\{\left(\Delta \mathbf{w}_{\mathrm{t}}-\Delta \mathbf{w}^{\mathrm{t}}\right)^{c} \mathbf{Q}\left(\Delta \mathbf{w}_{\mathrm{t}}-\Delta \mathbf{w}^{\mathrm{t}}\right)+\theta\left(\Delta \mathrm{r}_{\mathrm{t}}\right)^{2}\right\}
$$

Q adalah matrik $3 \times 3$ yang memperhitungkan preferensi jangka pendek bank sentral dalam pencapaian sasaran akhir kebijakan moneter, yaitu stabilisasi harga, output riil, dan kesempatan 
kerja. ${ }^{4}$ Selanjutnya, term terakhir dimaksudkan untuk menangkap adanya biaya penyesuaian (cost of adjustments) dari penggunaan sasaran operasional atau instumen kebijakan (policy instrument), $\mathrm{r}_{\mathrm{t}}{ }^{5}$

Selanjutnya, komponen yang sistematis dari suatu respons kebijakan moneter, , ditentukan dengan meminimumkan $\mathrm{E}\left\{\mathrm{C}\left[\left(\Delta \mathbf{w}_{\mathrm{t}^{\prime}} \Delta \mathbf{r}_{\mathrm{t}}\right) \mid \Psi_{\mathrm{t}-1}\right]\right\}$ dengan memperhitungkan adanya "common knowledge" mengenai keterkaitan antara target variable, $\mathbf{w}_{\mathrm{t}^{\prime}}$ dengan policy instrument, $\mathrm{r}_{\mathrm{t}}$, yang dapat diturunkan sebagai sub-sistem dari suatu model umum struktural error correction model, sebagai berikut:

$$
\Delta \mathbf{w}_{\mathrm{t}}=\prod_{\mathrm{ww}}+\prod_{\mathrm{wr}} \Delta \mathrm{r}_{\mathrm{t}}+\prod_{\mathrm{w}} \mathrm{x}\left(\mathbf{a}_{1} \mathrm{t}-\beta^{\prime} \mathbf{z}_{\mathrm{t}-1}\right)+\sum_{i=1}^{s-1} \prod_{\mathrm{i}, \mathrm{wz}} \Delta \mathbf{z}_{\mathrm{t}-\mathrm{i}}+\mathbf{u}_{\mathrm{t}, \mathrm{ww}}
$$

, dimana: $\prod_{w w}, \prod_{w r}, \prod_{w} \xi, \prod_{i, w z}$ dan $u_{t, w w}$ adalah matrik parameter sistem persamaan reduced form yang mengkaitkan target variables dengan policy instruments. Sementara itu, secara aplikatif, matrik parameter tersebut dapat dijabarkan sebagai berikut: ${ }^{6}$

$\begin{aligned} \prod_{w w(3 \times 1)} & =\left[\begin{array}{c}w_{p 0} \\ w_{y 0} \\ w_{n 0}\end{array}\right] \text { adalah matrik parameter konstan. } \\ \prod_{w r(3 \times 1)} & =\left[\begin{array}{c}r_{p r} \\ r_{y r} \\ r_{n r}\end{array}\right] \text { adalah matrik parameter keterkaitan antara target variables }(\mathrm{p}, \mathrm{y}, \mathrm{n}) \text { dan policy }\end{aligned}$ instruments $(r)$.

$\prod_{\mathrm{w}} \mathrm{x}_{(3 \times 4)}=\left[\begin{array}{llll}\xi_{p P P P} & \xi_{p E D E} & \xi_{p M M E} & \xi_{p I R P} \\ \xi_{y P P P} & \xi_{y E D E} & \xi_{y M M E} & \xi_{y I R P} \\ \xi_{n P P P} & \xi_{n E D E} & \xi_{n M M E} & \xi_{n I R P}\end{array}\right]$ adalah matrik penyesuaian perilaku target

variables terhadap perilaku keseimbangan jangka panjang dalam sistem.

$\prod_{i, w z(3 \times 9)}=\left[\begin{array}{ccccccccc}z_{p r} & z_{p p} & z_{p y} & z_{p n} & z_{p p^{*}} & z_{p e} & z_{p m} & z_{p s} & z_{p r^{*}} \\ z_{y r} & z_{y p} & z_{y y} & z_{y n} & z_{y p^{*}} & z_{y e} & z_{y m} & z_{y s} & z_{y r^{*}} \\ z_{n r} & z_{n p} & z_{n y} & z_{n n} & z_{n p^{*}} & z_{n e} & z_{n m} & z_{n s} & z_{n r^{*}}\end{array}\right]$ adalah matrik respons

perilaku target variables terhadap perilaku dinamis jangka pendek variabel-variabel dalam sistem.

\footnotetext{
4 Dalam formulasi umum persamaan (IV.27), dimungkinkan adanya fleksibilitas dalam penetapan sasaran akhir kebijakan moneter, yang tidak hanya terbatas merujuk pada adanya "trade-off" jangka pendek antara perkembangan harga dan output, namun juga aspek lainnya seperti peningkatan kesempatan kerja. Dengan demikian terjadi peningkatan dimensi matrik preferensi, Q, dan perubahan formulasi fungsi kerugian, tidak seperti formulasi pada umumnya.

5 Sebagaimana pula dalam kajian yang dilakukan oleh Svensson (1997).

6 Penurunan detail dari persamaan (IV.30) dapat dilihat di Lampiran.
} 
$\mathbf{u}_{t, w w(3 \times 1)}=\left[\begin{array}{l}u_{p} \\ u_{y} \\ u_{n}\end{array}\right]$ adalah matrik residual.

First-order condition dari minimisasi persamaan (IV.29) dengan subyek persamaan (IV.30) adalah:

$$
E\left[\left(\frac{\partial \Delta w_{t}}{\partial \Delta r_{t}}\right)^{\prime} Q\left(\Delta w_{t}-\Delta w^{t}\right)+\theta \Delta r_{t} \mid \psi_{t-1}\right]=0
$$

Dengan mensubstitusikan $\Delta \mathbf{w}_{\mathrm{t}}$ dari persamaan (IV.31), dimana $\partial \Delta \mathbf{w}_{\mathrm{t}} / \partial \Delta \mathbf{r}_{\mathrm{t}}=\prod_{w r^{\prime}}$ maka didapatkan:

$$
\begin{aligned}
0= & \prod_{\mathrm{wr}}^{,} \mathbf{Q}\left[\left(\prod_{\mathrm{ww}}-\Delta \mathbf{w}^{\mathrm{t}}\right)+\prod_{\mathrm{wr}} \mathrm{E}\left[\Delta \mathrm{r}_{\mathrm{t}} \mid \Psi_{\mathrm{t}-1}\right]+\prod_{\mathrm{w}} \xi\left(\mathbf{a}_{1} \mathrm{t}-\beta^{\prime} \mathbf{z}_{\mathrm{t}-1}\right)\right. \\
& \left.+\sum_{i=1}^{s-1} \prod_{\mathrm{i}, \mathrm{wz}} \Delta \mathbf{z}_{\mathrm{t}-\mathrm{i}}+\mathbf{u}_{\mathrm{t}, \mathrm{ww}}\right]+\theta \mathrm{E}\left[\Delta \mathbf{r}_{\mathrm{t}} \mid \Psi_{\mathrm{t}-1}\right]
\end{aligned}
$$

Dengan pengelompokan parameter dari instrumen kebijakan, diperoleh:

$$
\begin{aligned}
-\left(\theta+\prod_{w r}^{\prime} \mathbf{Q} \prod_{w r}\right) E\left[\Delta r_{t} \mid \Psi_{t-1}\right]= & \prod_{w r}^{\prime} \mathbf{Q}\left[\left(\prod_{w w}-\Delta \mathbf{w}^{t}\right)+\prod_{w} \xi\left(\mathbf{a}_{1} t-\beta^{\prime} \mathbf{z}_{\mathrm{t}-1}\right)\right. \\
& \left.+\sum_{i-1}^{s-1} \prod_{i, w z} \Delta \mathbf{z}_{\mathrm{t}-\mathrm{i}}+\mathbf{u}_{\mathrm{t}, \mathrm{ww}}\right]
\end{aligned}
$$

dan selanjutnya diperoleh:

$$
\begin{aligned}
\mathrm{E}\left[\Delta \mathrm{r}_{\mathrm{t}} \mid \Psi_{\mathrm{t}-1}\right]= & -\left(\theta+\prod_{\mathrm{wr}}^{\prime} \mathbf{Q} \prod_{\mathrm{wr}}\right)^{-1} \prod_{\mathrm{wr}}^{\prime} \mathbf{Q}\left[\left(\prod_{\mathrm{ww}}-\Delta \mathbf{w}^{\mathrm{t}}\right)+\prod_{\mathrm{w}} \xi\left(\mathbf{a}_{1} \mathrm{t}-\beta^{\prime} \mathbf{z}_{\mathrm{t}-1}\right)\right. \\
& +\sum_{i=1}^{s-1} \prod_{\mathrm{i}, \mathrm{wz}} \Delta \mathbf{z}_{\mathrm{t}-\mathrm{i}}+\mathbf{u}_{\mathrm{t}, \mathrm{ww}}
\end{aligned}
$$

Dapat dilihat bahwa perilaku kebijakan moneter pada dasarnya dipengaruhi oleh nilai parameterparameter struktural utama, yaitu $\mathbf{Q}, \prod_{w r}, \prod_{w w}, \prod_{w} \xi$, dan $\prod_{w z^{\prime}}$ dimana parameter $\mathbf{Q}$, dapat dijabarkan dalam bentuk matrik parameter sebagai:

$\mathbf{Q}_{(3 \times 3)}=\left[\begin{array}{lll}\lambda_{p p} & \lambda_{p y} & \lambda_{p n} \\ \lambda_{y p} & \lambda_{y y} & \lambda_{y n} \\ \lambda_{n p} & \lambda_{n y} & \lambda_{n n}\end{array}\right]$, dan $\lambda$ adalah parameter yang terkait dengan preferensi otoritas moneter dalam penetapan prioritas di antara stabilisasi harga, output, dan kesempatan kerja. Persamaan (IV.34) di atas dapat dituliskan dalam bentuk yang lebih sederhana sebagai:

$$
\begin{aligned}
& \mathrm{E}\left[\Delta \mathrm{r}_{\mathrm{t}} \mid \Psi_{\mathrm{t}-1}\right]=\varphi_{0}+\varphi^{c}{ }_{1}\left(\mathbf{a}_{1} \mathrm{t}-\beta^{\prime} \mathbf{z}_{\mathrm{t}-1}\right)+\sum_{i=1}^{s-1} \varphi_{\mathrm{i}, 2}{ }^{c} \Delta \mathbf{z}_{\mathrm{t}-\mathrm{i}} \\
& \text {, dimana } \varphi_{0}=\Upsilon^{\prime}\left(\prod_{\mathrm{ww}}-\Delta \mathbf{w}^{\mathrm{t}}\right) \text {, } \\
& \varphi^{{ }_{1}}{ }_{1}=\Upsilon^{\prime} \prod_{\mathrm{w}} \xi \text {, } \\
& \varphi^{\prime}{ }_{i, 2}=\Upsilon^{\prime} \prod_{i, w z}, \\
& \Upsilon^{\prime}=-\left(\theta+\prod_{\text {wr }}^{\prime} \prod_{\text {wr }}\right)^{-1} \prod^{\prime}{ }_{w r} \mathbf{Q}
\end{aligned}
$$


Secara sederhana, bagian sebelah kiri persamaan (IV.35) dapat dijabarkan sebagai $\mathrm{E}\left[\Delta \mathrm{r}_{\mathrm{t}} \mid \Psi_{\mathrm{t}-1}\right]$ $=\mathrm{E}\left[\mathrm{r}_{\mathrm{t}}-\mathrm{r}_{\mathrm{t}-1} \mid \Psi_{\mathrm{t}-1}\right]=\mathrm{E}\left[\mathrm{r}_{\mathrm{t}} \mid \Psi_{\mathrm{t}-1}\right]-\mathrm{E}\left[\mathrm{r}_{\mathrm{t}-1} \mid \Psi_{\mathrm{t}-1}\right]=\mathrm{r}_{\mathrm{t}}^{\mathrm{s}}-\mathrm{r}_{\mathrm{t}-1}$. Dengan pemahaman bahwa komponen yang sistematis dari suatu respons kebijakan moneter adalah $r_{t}^{s}=E\left[r_{t} \mid \psi_{t-1}\right]$, maka feedback rule atau reaction function diperoleh sebagai berikut:

$$
\mathrm{r}_{\mathrm{t}}^{\mathrm{s}}-\mathrm{r}_{\mathrm{t}-1}=\varphi_{0}+\varphi_{1}^{\mathrm{c}}\left(\mathbf{a}_{1} \mathrm{t}-\beta^{\prime} \mathbf{z}_{\mathrm{t}-1}\right)+\sum_{i-1}^{s-1} \varphi_{\mathrm{i}, 2}^{\mathrm{c}} \Delta \mathbf{z}_{\mathrm{t}-\mathrm{i}}
$$

Sebagaimana diasumsikan sebelumnya bahwa shocks kebijakan moneter , $\varepsilon_{\mathrm{rt}}$, ditaksir sebagai komponen yang tidak sistematis dari respons kebijakan moneter. Dengan kata lain, shocks kebijakan moneter tersebut dapat didefinisikan sebagai perbedaan antara perilaku sasaran operasional atau instrumen kebijakan yang terjadi/aktual, $\mathrm{r}_{\mathrm{t}}$, dengan perilaku komponen yang sistematis dari suatu respons kebijakan moneter, $\mathrm{r}_{\mathrm{t}}^{\mathrm{s}}$, atau dapat dituliskan:

$$
\varepsilon_{\mathrm{rt}}=\mathrm{r}_{\mathrm{t}}-\mathrm{r}_{\mathrm{t}}^{\mathrm{s}}
$$

Dengan menggunakan (IV.35); (IV.36) dan (IV.37), diperoleh keterkaitan struktural untuk persamaan perilaku instrumen yang konsisten dengan karakteristik jangka panjang dari model strutural yang dispesifikasikan dalam persamaan (IV.26), yaitu:

$$
\Delta \mathrm{r}_{\mathrm{t}}=\varphi_{0}+\varphi_{1}^{6}\left(\mathbf{a}_{1} \mathrm{t}-\beta^{\prime} \mathbf{z}_{\mathrm{t}-1}\right)+\sum_{i=1}^{s-1} \varphi_{\mathrm{i}, 2}^{c} \Delta \mathbf{z}_{\mathrm{t}-\mathrm{i}}+\varepsilon_{\mathrm{rt}}
$$

\section{HASIL PENAKSIRAN DAN ANALISIS MODEL}

Data yang digunakan dalam penelitian adalah data triwulanan dengan rentang waktu 1980.1 - 2003.4. Dalam hal variabel tersedia dalam bentuk data tahunan, maka akan dilakukan interpolasi data menjadi data triwulanan. Sementara itu, untuk data yang tersedia dalam bentuk data bulanan, maka data triwulanan dihitung secara rata-rata bergerak (quarterly moving average). Dalam kaitan tersebut, data yang diidentifikasi dalam penelitian ini meliputi:

(a) inflasi domestik, yang diukur dengan menggunakan Indeks Harga Konsumen (IHK) tahun dasar 1996;

(b) tingkat output, yang diukur dengan menggunakan angka Produk Domestik Bruto (PDB) tahun dasar 1993; ${ }^{7}$

\footnotetext{
7 Data PDB riil (harga konstan atas tahun dasar) secara triwulan tersedia mulai tahun 1980. Data yang merupakan "flow data" mulai tahun 1974 sampai dengan 1979 diperoleh melalui transformasi data tahunan menjadi triwulanan melalui metode "interpolasi deskriptif". Metode interpolasi ini dianggap lebih reprsentatif dibandingkan dengan metode interpolasi deterministik (seperti spline regression, a local quadratic polynomial, maupun metode ala Insukindro dan A.C. Diz) yang cenderung "smoother" dalam menjelaskan perilaku triwulanan PDB riil (siklikal dan musiman). Beberapa langkah dalam metode "interpolasi deskriptif" adalah sebagai berikut. Pertama, dengan mengasumsikan bahwa terdapat keterkaitan jangka panjang antara deflator PDB dengan IHK, dilakukan taksiran perubahan deflator PDB berdasarkan perubahan IHK. Kedua, melakukan taksiran PBD riil, yaitu dengan membagi PDB nominal dengan taksiran deflator PDB. Terakhir, melakukan validasi nilai taksiran perubahan triwulanan dengan menyesuaikannya terhadap restriksi perubahan tahunan. Berdasarkan metode interpolasi ini, diperoleh data triwulanan PDB riil yang mempunyai kecenderungan perubahan siklikal dan musiman yang relatif representatif, serta memenuhi kondisi dimana perubahan total selama 4 (empat) triwulan sama dengan perubahan tahunan.
} 
(c) kesempatan kerja/tingkat pengangguran, yang diukur dengan menggunakan angka kesempatan kerja/pengangguran menurut definisi baku yang digunakan oleh Badan Pusat Statistik (BPS); 8

(d) besaran moneter, yang diukur dengan menggunakan data indikator besaran moneter dalam artian sempit dan sekaligus merupakan sasaran operasional kebijakan, yaitu uang primer (M0);

(e) suku bunga, yang diukur dengan menggunakan data suku bunga Sertifikat Bank Indonesia (SBI), dengan jangka waktu 3 bulan; 9

(f) nilai tukar, yang diukur dengan menggunakan nilai tukar (kurs) mata uang rupiah terhadap US\$ (kurs pasar);

(g) indeks harga saham, yang diukur dengan menggunakan angka Indeks Harga Saham Gabungan (IHSG) tahun dasar 1982;10

(h) inflasi luar negeri, yang diukur dengan menggunakan Indeks Harga Konsumen (IHK) perekonomian Amerika Serikat tahun dasar 1996;

(i) suku bunga luar negeri, yang diukur dengan menggunakan suku bunga London Interbank Over-Rates (LIBOR) jangka waktu 3 bulan.

Secara umum, data tersebut merupakan data skunder dan bersumber dari Badan Pusat Statistik (BPS), Bank Indonesia (BI), dan sumber-sumber lain lain.

\section{III.1 Hasil Penaksiran Model Makro Structural Cointegrating VAR}

Model makro structural cointegrating VAR yang ditaksir didasarkan pada formulasi persamaan (IV.25) atau (IV.26), yaitu:

$$
\begin{aligned}
& \Delta \mathbf{z}_{\mathrm{t}}=\mathbf{b}-\boldsymbol{\alpha} \xi_{\mathrm{t}}+\sum_{i-1}^{s-1} \Gamma_{\mathrm{i}} \Delta \mathbf{z}_{\mathrm{t}-\mathrm{i}}+\mathbf{u}_{\mathrm{t}} \\
& \Delta \mathrm{z}_{\mathrm{t}}=\mathbf{c}+\boldsymbol{\alpha}\left(\mathbf{a}_{1} \mathrm{t}-\beta^{\prime} \mathbf{z}_{\mathrm{t}-1}\right)+\sum_{i-1}^{s-1} \Gamma_{\mathrm{i}} \Delta \mathbf{z}_{\mathrm{t}-\mathrm{i}}+\mathbf{u}_{\mathrm{t}}
\end{aligned}
$$

, dimana $\mathbf{c}=\mathbf{b}+\mathbf{a}\left(\mathbf{a}_{1}-\mathbf{a}_{0}\right)$ dan $\xi_{\mathrm{t}}=\beta^{\prime} \mathbf{z}_{\mathrm{t}-1}$ adalah error correction terms

8 Data tingkat penganggguran yang merupakan "stock data" secara triwulanan diperoleh dengan menggunakan metode interpolasi "quadratic-polynomial-match-sum" yang ditaksir dengan menggunakan program E-Views (lihat topik Frequency Conversion).

9 Data suku bunga SBI tersedia sejak tahun 1984. Mengingat secara empiris suku bunga SBI merupakan reference rate bagi perkembangan suku bunga pasar uang dan dana, maka data suku bunga SBI sebelum masa tersebut ditaksir dengan menggunakan proksi berdasarkan koefisien elastisitas jangka panjang antara suku bunga SBI dengan suku bunga pasar dana (deposito). Sementara itu, digunakannya suku bunga SBI 3 bulan, bukan SBI1 bulan, dilandasi oleh dua pertimbangan. Pertama, dari hasil pengujian statistik, terdapat keterkaitan yang sangat erat dan kesamaan karakteristik antara suku bunga SBI 3 bulan dan SBI 1 bulan. Kedua, penggunaan indikator suku bunga SBI 1 bulan memiliki keterbatasan mengingat ketidaktersediaan data tersebut pada beberapa periode observasi, terutama pada periode sebelum tahun 1989.

10 Untuk tahun sebelum 1982 (1980 dan 1981) menggunakan indeks 100. 
Dengan menggunakan pendekatan dalam Pesaran and Shin (1997); Pesaran, Shin, and Smith (1997); dan Pesaran and Smith (1998), tahapan prosedur penaksiran baku yang dilakukan meliputi:

(i) Pengujian stasioneritas atau unit root univariat masing-masing variabel dalam VAR untuk menentukan derajat kointegrasi dengan menggunakan Augmented Dickey-Fuler (ADF) test;

(ii) Pemilihan order dari model VAR model dengan menggunakan selection criteria berdasarkan kriteria informasi Akaike Information Criterion (AIC) dan Schwarz Bayesian Criterion (SBC), maupun Hannan-Quinn Criterion (HQC);

(iii) Pengujian jumlah keterkaitan kointegrasi di antara variabel dalam $\mathbf{z}_{\mathrm{t}^{\prime}}$

(iv) Penaksiran vector error correction model (VECM) berdasarkan cointegrating VAR.

(v) Analis persistence profiles.

Perlu dikemukakan bahwa tahapan pendekatan di atas merupakan pengembangan dan sekaligus generalisasi analisis cointegrating VAR yang dikemukakan oleh Johansen (1991) dan Johansen and Juselius (1992), yang dikenal dengan Johansen's maximum likelihood approach. Dalam hal ini, paling tidak terdapat tiga aspek pengembangan. Pertama, penaksiran cointegrating VAR dilakukan dengan menggunkan restriksi berdasarkan apriori teoritis - exact identification; dan pengujian over identifying restrictions. Selain itu, dalam pendekatan di atas dimungkinkan penyertaan forcing variables, yaitu variabel di luar $\mathbf{z}_{\mathrm{t}}$ yang mempengaruhi sistem. Yang terakhir adalah dimungkinkannya dilakukan analisis persistence profiles untuk melihat kecepatan sejauhmana penyesuaian untuk kembali kepada keseimbangan apabila terjadi shocks pada keterkaitan antar variabel dalam sistem.

Adapun hasil penaksiran disampaikan pada beberapa bagian berikut.

\section{III.1.1 Pengujian Stasioneritas}

Pengujian stasioneritas dilakukan dengan menggunakan uji statsioneritas, Augmented Dickey-Fuller (ADF). Dari hasil pegujian pada tingkat signifikasi 95\% dan batas pengujian pada lag sama dengan 4," dapat diperlihatkan bawa dalam bentuk level, pengujian pada umumnya tidak dapat menolak hipotesis nol tentang adanya unit-root pada semua variabel (kecuali suku bunga RSBI dan RLIB), yang berarti bahwa semua variabel (kecuali suku bunga) bersifat nonstasioner pada tingkat signifikasi 95\%. Sementara itu, dalam bentuk first difference, hasil pengujian menolak hipotesis nol tentang adanya unit-root pada semua variabel semua variabel

11 Untuk variabel dalam bentuk level, statistik uji statsioneritas, Augmented Dickey-Fuller(ADF) statistics, dihitung berdasarkan persamaan regresi dengan parameter konstant (intercept), tren linier, dan beberapa lag dari variabel dependen (sampai dengan 4). Sementara itu, untuk variabel dalam bentuk first-difference, ADF-statistics dihitung berdasarkan persamaan regresi hanya dengan parameter konstan dan dan beberapa lag dari variabel dependen. 
bersifat stasioner. Suku bunga mempunyai signifikasi derajat penolakan terhadap nilai kritis yang lebih besar. Dari hasil tersebut dapat disimpulkan bahwa semua variabel dalam sistem memiliki derajat integrasi 1, atau I(1). Dalam hal ini, suku bunga cenderung bersifat "close to (non) stasionary". [Tabel IV.3.1]

\begin{tabular}{|c|c|c|c|c|c|c|}
\hline \multicolumn{7}{|c|}{$\begin{array}{c}\text { Tabel IV.3.1.a } \\
\text { Hasil Uji Stasioneritas }\end{array}$} \\
\hline \multicolumn{7}{|c|}{ For the levels: The Dickey-Fuller regressions include an intercept and a linear trend } \\
\hline & DF & ADF(1) & ADF(2) & ADF(3) & ADF(4) & $\begin{array}{c}95 \% \text { CV for } \\
\text { ADF }\end{array}$ \\
\hline RSBI & -2.39 & -4.37 & -3.76 & -4.40 & -3.19 & -3.46 \\
\hline LIHK & -1.47 & -2.32 & -2.61 & -2.23 & -2.22 & -3.45 \\
\hline LY & -2.08 & -1.77 & -0.98 & -0.42 & -1.86 & -3.45 \\
\hline LN & -1.75 & -4.33 & -3.70 & -3.09 & -2.66 & -3.46 \\
\hline LIHKUS & -0.07 & -0.18 & -0.13 & 0.00 & 0.00 & -3.46 \\
\hline LKURS & -2.31 & -3.02 & -3.51 & -2.64 & -2.95 & -3.45 \\
\hline LMO & -1.13 & -1.25 & -1.21 & -1.11 & -1.60 & -3.45 \\
\hline LM1 & -2.17 & -2.35 & -2.35 & -2.25 & -2.48 & -3.45 \\
\hline LM2 & 0.31 & -0.85 & -0.98 & -0.87 & -1.76 & -3.45 \\
\hline USX & -1.42 & -2.03 & -2.09 & -2.47 & -2.56 & -3.46 \\
\hline RLIB & -4.18 & -4.39 & -4.30 & -4.58 & -3.62 & -3.46 \\
\hline
\end{tabular}

\section{Tabel IV.3.1.b.}

\section{Hasil Uji Stasioneritas}

For the first differences. The Dickey-Fuller regressions include an intercept but not a trend

\begin{tabular}{|c|c|c|c|c|c|c|}
\hline & DF & ADF(1) & $\operatorname{ADF}(2)$ & ADF(3) & ADF(4) & $\begin{array}{c}95 \% \text { CV for } \\
\text { ADF }\end{array}$ \\
\hline $\mathrm{D}(\mathrm{RSBI})$ & -5.82 & -6.08 & $-4.79^{h}$ & -6.03 & -5.90 & -2.89 \\
\hline$D($ LIHK) & -6.62 & $-5.19^{h}$ & -5.42 & -5.00 & -5.05 & -2.89 \\
\hline$D(L Y)$ & -12.05 & -11.51 & -10.32 & $-3.82^{h}$ & -4.01 & -2.89 \\
\hline$D(L N)$ & -4.32 & -4.87 & -5.32 & $-5.51^{h}$ & -5.14 & -2.89 \\
\hline D(LIHKUS) & -6.26 & -5.92 & $-3.90^{h}$ & -3.81 & -3.79 & -2.89 \\
\hline D(LKURS) & -8.15 & -5.75 & $-6.96^{h}$ & -5.25 & -5.20 & -2.89 \\
\hline $\mathrm{D}(\mathrm{LMO})$ & -9.32 & -7.11 & -6.22 & $-4.05^{h}$ & -4.26 & -2.89 \\
\hline$D(L M 1)$ & -8.86 & -6.60 & -6.07 & $-4.20^{h}$ & -4.37 & -2.89 \\
\hline $\mathrm{D}(\mathrm{LM} 2)$ & -7.15 & -5.63 & -5.07 & $-3.51^{h}$ & -3.64 & -2.89 \\
\hline$D($ LJSX) & -6.64 & $-5.29^{h}$ & -3.96 & -3.60 & -3.23 & -2.89 \\
\hline$D(R L I B)$ & -8.41 & $-6.54^{h}$ & -4.74 & -4.02 & -3.37 & -2.89 \\
\hline
\end{tabular}


Perlu dikemukakan bahwa nilai kritis (critical values) yang relevan diacu dari ADF-test adalah $5 \%$, yaitu masing-masing -3.45 (-3.46) dan -2.89. Angka statistik yang "ditebali" menujukkan order of augmentation yang dipilih berdasarkan derajat penolakan tertinggi terhadap hipotesis nol tentang adanya " unit root". Sementara itu, simbol " $\mathrm{h}$ " menunjukkan order of augmentation yang dipilih berdasarkan kriteria informasi Hannan-Quinn Criterion (HQC). Dari kedua aspek tersebut dapat disimpulkan bahwa order of augmentation berkisar antara 1 dan 3.

Pengamatan karakteristik perkembangan suatu variabel merupakan tahap awal yang sangat penting. Untuk itu, sebagai perbandingan, uji stasioneritas juga dilakukan secara terpisah dengan menggunakan beberapa metode lain, yaitu metode non-parametrik Phillips-Perron (PP) test, serta dua metode lain yang masing-masing merupakan modifikasi dari dari ADF test dan PP test, yaitu Elliot-Rothenber-Stock (ERS) test dan Ng-Perron (NP) test. Dengan adanya kemungkinan terjadinya perubahan perilaku data, metode tersebut dapat diterapkan dengan kemampuan untuk mengontrol terjadinya serial korelasi derajat tinggi dari perilaku error terms.

PP-test didasarkan pada regresi persamaan dengan proses $A R(1)$ seperti halnya pada non-augmented Dickey-Fuller test, sementara koreksi non-parametrik dilakukan pada statistikt dari koefisien regresi dengan menggunakan taksiran dari spektrum pada frekuensi nol, yang handal terhadap permasalahan heteroskedastisitas dan otokorelasi (dengan pola yang tidak diketahui). Berikutnya, ERS test merupakan modifikasi sederhana dari ADF test, dimana sebelum dilakukan penaksiran regresi, unsur-unsur yang bersifat 'explanatory' dari perilaku data, termasuk trend, dihilangkan (GLS detrended data) terlebih dahulu. Hal ini menghindari implikasi penaksiran yang terkait dengan pengikutsertaan konstanta saja atau konstanta dan trend. Sementara itu, NP test merupakan modifiksi dari PP test yang didasarkan pada GLS detrended data.

Adapun hasil pengujian PP test, ERS test, dan NP test memberikan kesimpulan yang secara umum sama dengan hasil pengujian ADF test, yaitu bahwa variable-variabel makro yang ada dalam sistem permodelan mempunyai karakteristik I(1), yaitu non-stasioner pada bentuk level, tapi stasioner pada bentuk first-difference. Namun, satu hal yang perlu mendapatkan perhatian lebih adalah menyangkut karakteristik perkembangan suku bunga SBI (RSBI), yang sejak periode pasca krisis ekonomi 1997 juga menunjukkan perannya sebagai sasaran operasional kebijakan moneter, bersama-sama dengan uang primer. Berdasarkan PPtest, level suku bunga SBI menunjukkan perilaku yang non-stasioner (tingkat signifikasi 95\%), sementara menurut ketiga metode lainnya, perilaku suku bunga SBI bersifat "close to (non) stationarity".

Isu yang muncul selanjutnya menyangkut keterkaitan antara perbedaan karakteristik perkembangan suku bunga SBI pada periode sebelum dan sesudah krisis ekonomi 1997 dengan 
hasil pengujian stasioneritas tersebut. Apabila terjadi perbedaan yang sangat tajam maka hal tersebut tentunya akan berdampak pada penarikan kesimpulan hasil penaksiran sistem permodelan secara keseluruhan. Secara intuitif, terdapat potensi perbedaan karakteristik perkembangan suku bunga SBI, antara lain terkait dengan semakin besarnya peran suku bunga SBI dalam pengendalian moneter, perubahan mekanisme lelang dalam OPT, dan krisis ekonomi 1997. Namun, hal tersebut perlu diamati lebih lanjut.

Dari Grafik IV.3.1 dapat dilihat bahwa secara keseluruhan perkembangan suku bunga $\mathrm{SBI}$ dalam level (RSBI) mengandung unsur trend (trend stationary), sementara dalam first difference $(\mathrm{D}(\mathrm{RSBI}))$ bersifat stasioner. Fenomena menarik dapat dilihat pada periode pasca krisis ekonomi 1997, dimana walaupun sempat terjadi lonjakan drastis pada periode 1997.3 - 1999, pada periode setelahnya perilaku perkembangan suku bunga kembali kepada kecenderungan sebelum krisis.

Dari hasil pengujian regresi autoregressive terhadap perkembangan suku bunga SBI, dihasilkan parameter autoregressive sebesar 0.87 untuk seluruh periode. Pengujian pada dua sub-sampel menghasilkan parameter autoregressive 0.92 pada periode sebelum krisis dan 0.85 pada periode setelah krisis, sementara uji restriksi parameter pada kedua parameter tersebut menunjukkan bahwa secara statistik keduanya sama dengan 0.87. Dari hasil tersebut disimpulkan bahwa, walaupun terdapat perbedaan derajat persistensi pada karakteristik perkembangan suku bunga SBI pada periode sebelum dan sesudah krisis ekonomi 1997, perbedaan tersebut secara ststistik tidak signifikan. Hasil tersebut didukung oleh hasil analisis persistensi dengan menggunakan analisis spektrum (spectral analysis), yang secara keseluruhan menympulkan adanya kesamaan karakteristik, baik derajat persistensi maupun kesamaan pola pada perilaku perkembangan suku bunga SBI pada periode sebelum dan sesudah krisis ekonomi 1997 [Grafik IV.3.2].

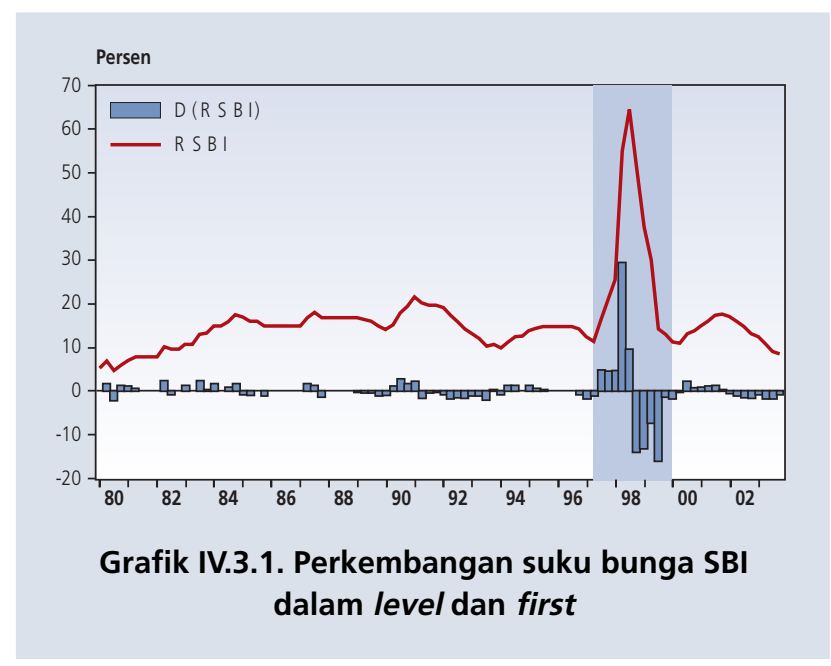



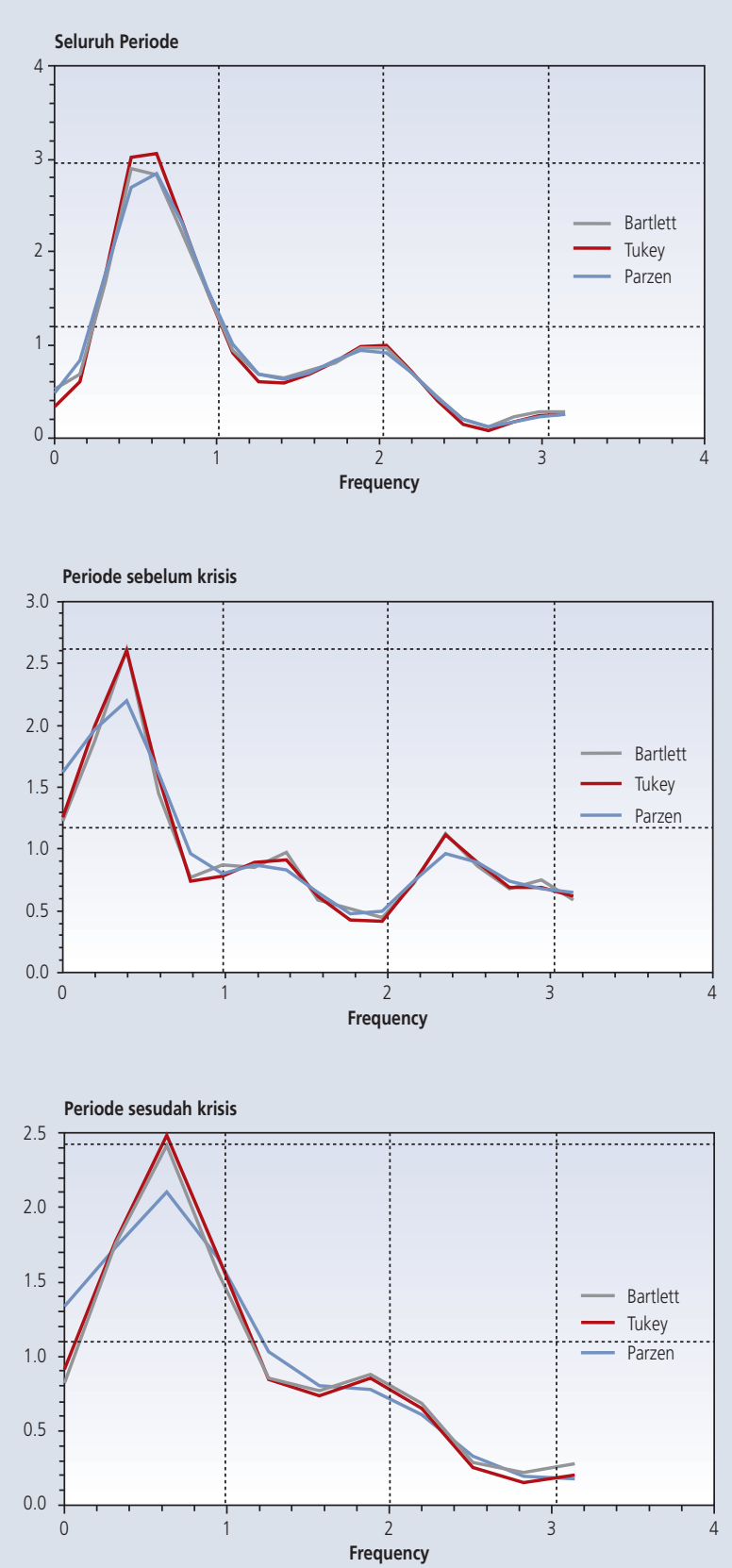

Grafik IV.3.2. Fungsi kepadatan spektrum suku bunga SBI (D(RSBI)) 


\section{III.1.2 Pemilihan Panjang Lag dan Jumlah Keterkaitan Kointegrasi}

Pemilihan panjang lag (order) dilakukan dengan menggunakan tolok ukur kriteria informasi (information criteria), yaitu Akaike Infotmation Criterion (AIC) dan Schwarz Bayesian Criterion (SBC), maupun Hannan-Quinn Criterion (HQC). ${ }^{12}$ Pada penelitian ini batas maksimal lag yang diperhitungkan adalah empat. Dari hasil pengujian berdasarkan SBC, order yang dipilih adalah satu, sementara berdasarkan AIC order yang dipilih adalah empat. Terdapat indikasi atau kemungkinan bahwa order berada di antara nilai "ekstrim" tersebut. Dengan demikian, aspek penting lain yang yang perlu dipertimbangkan adalah kondisi bahwa dengan rentang periode yang tidak terlalu lama, pemilihan order yang lebih pendek akan menghindari permasalahan "over-parametrization". Selain itu, dari uji statistik uji kestasioneran menunjukkan bahwa order of augmented variabel umumnya berkisar antara satu sampai dengan tiga. Berdasarkan beberapa informasi tersebut, dapat dipertimbangkan bahwa order model VAR yang "optimal" adalah dua. [Tabel IV.3.2]

\begin{tabular}{|c|c|c|c|c|c|}
\hline \multicolumn{6}{|c|}{$\begin{array}{c}\text { Tabel IV.3.2. } \\
\text { Hasil Uji Pemilihan Order VAR }\end{array}$} \\
\hline \multicolumn{6}{|c|}{ Test Statistics and Choice Criteria for Selecting the Order of the VAR Model } \\
\hline \multirow{2}{*}{\multicolumn{6}{|c|}{$\begin{array}{l}* * * * * * * * * * * * * * * * * * * * * * * * * * * * * * * * * * * * * * * * * * * * * * * * * * * * * * * * * * * * * * * * * * * * * * * \\
\text { Based on } 90 \text { observations from 1981Q3 to 2003Q4. Order of VAR }=4 \\
\text { List of variables included in the unrestricted VAR: }\end{array}$}} \\
\hline & & & & & \\
\hline $\mathrm{RSBI}$ & \multicolumn{2}{|c|}{ LIHK } & LY & LIHKUS & \\
\hline LKURS & & & LSX & RLIB & \\
\hline \multicolumn{6}{|c|}{ List of deterministic and/or exogenous variables: } \\
\hline \multicolumn{3}{|c|}{ KONSTAN $\quad T$} & & & \\
\hline Order & LL & $\mathrm{AIC}$ & SBC & LR test & Adjusted LR test \\
\hline 4 & 1450.6 & 1108.6 & 681.1333 & $\operatorname{CHSQ}(162)=487.2653[.000]$ & $184.0780[.113]$ \\
\hline 3 & 1367.2 & 1106.2 & 779.9549 & $\operatorname{CHSQ}(243)=654.1068[.000]$ & $247.1070[.415]$ \\
\hline 2 & 1264.6 & 1084.6 & 859.6261 & CHSQ(324)= 859.2490[.000] & $324.6052[.480]$ \\
\hline 1 & 1142.6 & 1043.6 & 919.8776 & $\operatorname{CHSQ}(405)=1103.2[.000]$ & $416.7760[.332]$ \\
\hline 0 & 368.6 & 350.6 & 328.1232 & $\operatorname{CHSQ}(486)=2651.2[.000]$ & $1001.6[.000]$ \\
\hline
\end{tabular}

12 Konsep information criteria digunakan untuk mengukur informasi yang dapat dihimpun dalam penaksiran sistem permodelan, dimana dalam hal ini dilakukan penyeimbangan antara goodness of fit di satu sisi dan kesederhanaan spesifikasi model di lain sisi. Ketiga kriteria tersebut berbeda dalam menetapkan keseimbangan antara dua kepentingan tersebut. Formulasi ketiga kriteria tersebut adalah:

$\mathrm{AIC}=2 \mathrm{~L} / \mathrm{n}-2 \mathrm{k} / \mathrm{n}$

$\mathrm{SBC}=2 \mathrm{~L} n-k \log n / n$.

$\mathrm{HQC}=2 \mathrm{~L} n-2 k \log (\log n) / n$.

, dimana $k$ adalah jumlah parameter yang ditaksir, $n$ adalah jumlah obeservasi, dan $L$ adalah nilai log-likelihood dari persamaan dengan k parameter yang ditaksir. Dapat dilihat bahwa ketiga kriteria tersebut didasarkan pada 2 kali rata-rata nilai log-likelihood. Perbedaannya terletak pada besarnya penalti yang ditunjukkan pada ekspresi kedua. Dengan formulasi di atas, spesifikasi model yang dipilih adalah model dengan information criteria yang tertinggi. 
Sementara itu, pemilihan jumlah keterkaitan kointegrasi dalam sistem permodelan VAR dilakukan dengan menggunakan tolok ukur berdasarkan kriteria Maximal Eigenvalue, Trace Statistics, dan Model Selection Criteria (HQC). Berdasarkan Maximal Eigenvalue, hipotesis nol bahwa jumlah keterkaitan kointegrasi paling banyak adalah 1 ditolak, yang berarti bahwa terdapat 2 keterkaitan kointegrasi di antara variabel-variabel dalam sistem. Berdasarkan Trace Statistics, hipotesis nol bahwa jumlah keterkaitan kointegrasi paling banyak adalah 3 ditolak, yang berarti bahwa terdapat 4 atau lebih keterkaitan kointegrasi di antara variabel-variabel dalam sistem. Sementara itu, berdasarkan Model Selection Criteria (HQC), disimpulkan bahwa terdapat 5 keterkaitan kointegrasi di antara variabel-variabel dalam sistem. [Tabel IV.3.3]

Tabel IV.3.3.

\section{Hasil Uji Jumlah Keterkaitan Kointegrasi}

Cointegration with unrestricted intercepts and restricted trends in the VAR

94 observations from 1980Q3 to 2003Q4. Order of VAR $=2$.

List of variables included in the cointegrating vector:

RSBI LIHK LY

LKURS LMO LSX

LN

RLIB

$34255-28378$

$28378 \quad .16517$

List of eigenvalues in descending order:

$\begin{array}{ll}.53219 & .49091 \\ .085273 & .074877\end{array}$

Cointegration LR Test Based on Maximal Eigenvalue of the Stochastic Matrix

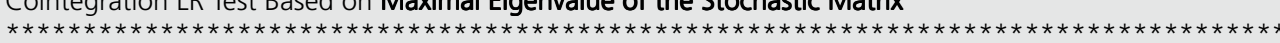

$\begin{array}{lll}r=0 & r=1 & 71.4119\end{array}$

$r<=1 \quad r=2 \quad 63.4630$

$r<=2 \quad r=3 \quad 43.0639$

$r<=3 \quad r=4 \quad 39.4221$

$\begin{array}{lll}r<=4 & r=5 & 31.3740\end{array}$

$r<=5 \quad r=6 \quad 16.9697$

$r<=6 \quad r=7 \quad 14.6655$

$\begin{array}{lll}r<=7 & r=8 & 8.3781\end{array}$

7.3158

95\% Critical Value

61.2700

55.1400

49.3200

43.6100

37.8600

31.7900

25.4200

19.2200

12.3900

$90 \%$ Critical Value

58.0900

52.0800

46.5400

40.7600

35.0400

29.1300

23.1000

$\mathrm{r}<=8$

$r=9$

10.5500

Use the above table to determine $r$ (the number of cointegrating vectors).

Cointegration LR Test Based on Trace of the Stochastic Matrix

Alternative Statistic

$r<=1 \quad r>=2 \quad 224.6521$

$r>=3 \quad 161.1891$

$\mathrm{r}>=4 \quad 118.1252$

$r>=5 \quad 78.7032$

$r>=6 \quad 47.3292$

$r>=7 \quad 30.3595$

$r>=8 \quad 15.6940$

$r=9$

7.3158

Critical Value

\% Critical Value

$222.6200-215.8700$

$\begin{array}{ll}182.9900 & 176.9200\end{array}$

$147.2700-141.8200$

$\begin{array}{ll}115.8500 & 110.6000\end{array}$

$87.1700-82.8800$

$63.0000 \quad 59.1600$

$42.3400 \quad 39.3400$

$25.7700 \quad 23.0800$

12.3900

Use the above table to determine $r$ (the number of cointegrating vectors). 


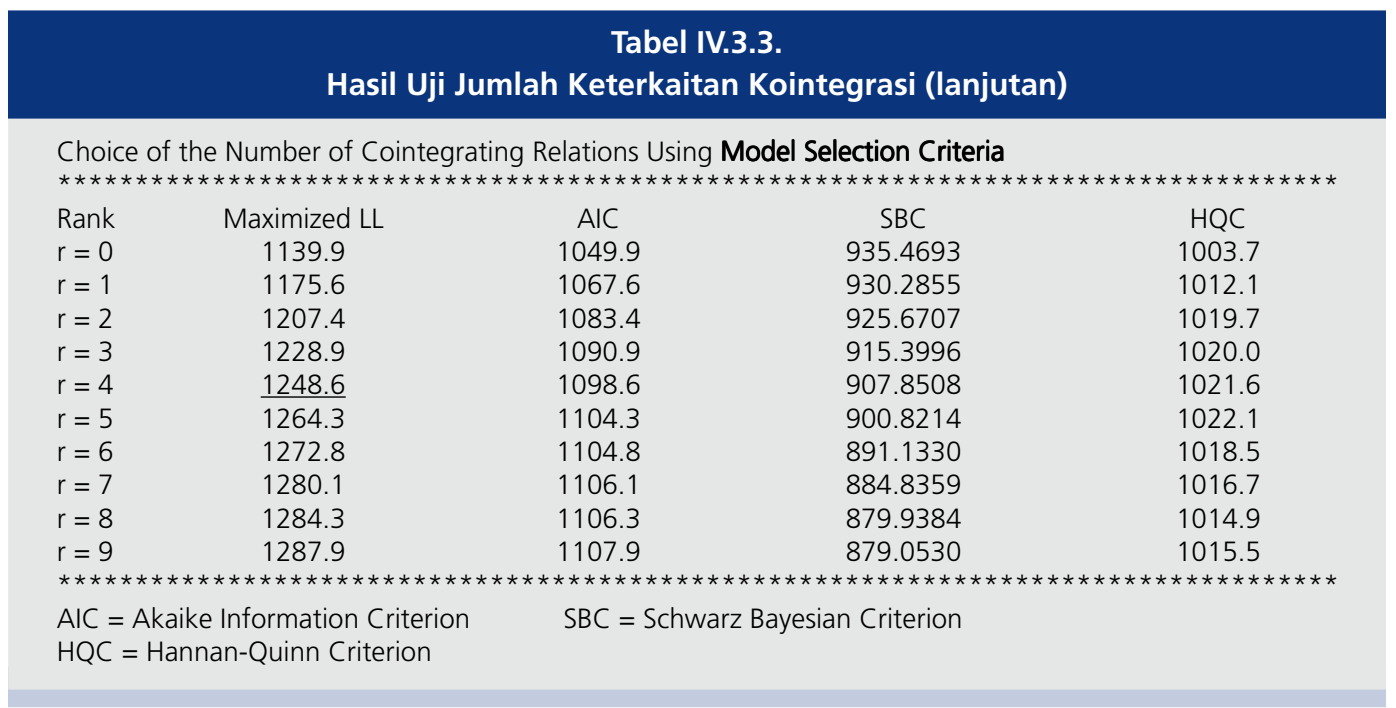

Dari hasil tersebut, dapat dilihat bahwa, secara statistik (dengan perbedaan hasil yang terjadi), jumlah keterkaitan kointegrasi berkisar antara 2, 4 atau 5. Dalam praktek pada umumnya, keputusan mengenai pemilihan jumlah keterkaitan kointegrasi harus tetap mengacu pada jugdment atau informasi lain, termasuk di antaranya adalah berdasarkan teori ekonomi, yang dalam hal ini mengidentifikasikan 4 keterkaitan kointegrasi. Dengan demikian, dapat disimpulkan bahwa hasil pengujian statistik cukup mendukung adanya 4 keterkaitan kointegrasi dalam sistem permodelan VAR.

\section{III.1.3 Penaksiran Model Cointegrating VAR}

Secara teknis, penaksiran Structural Cointegrating VAR dilakukan dengan memperhitungkan permasalahan indentifikasi sistem permodelan. Untuk itu, dilakukan pengujian restriksi identifikasi dalam sistem permodelan, yaitu identifikasi yang sesuai (exact identification restriction) dan identifikasi yang berlebih (over identification restriction). Dengan asumsi bahwa terdapat 4 keterkaitan kointegrasi, maka dibutuhkan 4 restriksi apriori yang independen pada masing-masing keterkaitan kointegrasi, sehingga dimungkinkan pengidentifikasian secara tepat (exact identification). Pada masing-masing vektor keterkaitan cointegrasi terdapat 10 elemen, yaitu 9 di antaranya merupakan variabel-variabel dalam sistem, yaitu vektor $\mathbf{z}_{\mathrm{t}}$ yang bersifat I(1) dan yang terakhir adalah time trend, sebagaimana ditunjukkan pada kolom pertama, Tabel IV.3.4.a .

Sementara itu, 16 restriksi apriori berdasarkan teori ekonomi yang diketengahkan adalah: $a 2=1 ; a 5=-1 ; a 6=-1 ; a 9=0 ; b 4=1 ; b 5=0 ; b 8=0 ; b 9=0 ; c 4=0 ; c 5=0 ; c 7=1 ; c 9=0 ; d 1=1 ; d 2=0 ;$ $d 3=0 ; d 9=-1$. Dalam kaitan ini, parameter a's (pada vektor 1), b's (pada vektor 2), c's (pada 
vektor 1), dan d's (pada vektor 1), masing-masing mencerminkan keterkaitan teoritis dalam keseimbangan Purchasing Power Parity (PPP), Employment Determination Equilibrium (EDE), Money Market Equilibrium (MME), dan Interest Rate Parity (IRP). Angka dalam kurung merupakan standard deviasi parameter. Sementara itu, nilai maksimum dari fungsi Log-likelihood adalah 1248.6, sama dengan nilai maksimum fungsi Log-likelihood pada rank 4. [Tabel IV.3.4.a]

Penaksiran berdasarkan restriksi apriori teoritis (exact identification restrictriction), 16 restriksi terhadap total 40 parameter dalam sistem, belum menunjukkan kinerja model yang baik, yang terlihat pada arah dan signifikasi parameter yang tidak sesuai dengan landasan teori. Dengan demikian, perlu melakukan penaksiran berdasarkan restriksi alternatif (over identification restrictriction), dengan mengacu pada disain "model inti" persamaan jangka panjang. Over identification restrictriction mengetengahkan 17 restriksi tambahan, sehingga total restriksi parameter berjumlah 33 terhadap 40 parameter dalam sistem.

Dari penaksiran terlihat bahwa pada tingkat signifikasi 95\%, pengujian menolak hipotesis nol bahwa keberadaan restriksi tambahan (over identification restriction) valid. Namun demikian, penaksiran parameter-parameter pada masing-masing persamaan jangka panjang mempunyai arah yang sesuai maupun besaran yang cukup reliable. Dengan mempertimbangkan kemungkinan bahwa uji restriksi Log-likelihood cenderung over reject serta adanya kesesuaian penaksiran parameter model, maka hasil penaksiran di atas dianggap representatif dan dapat dipergunakan untuk melakukan penaksiran (reduced form) vector error correcting model. [Tabel IV.3.4.b]

Selanjutnya, Long-Run Equilbrium Relationships diformulasikan sebagai berikut.

(1) Purchasing Power Parity (PPP):

LIHK - LIHKUS - LKURS $=-7.411-0.009 *$ Trend $+\xi_{1, t+1}$

(2) Employment Determination Equilibrium (EDE):

$\mathrm{LN}=7.286-0.019 * \mathrm{RSBI}+0.220 * \mathrm{LHHK}+0.300 * \mathrm{LY}-0.727 \mathrm{E}-3 *$ Trend $+\xi_{2, t+1}$

(3) Money Market Equilibrium (MME):

$\mathrm{LMO}-\mathrm{LIHK}=-11.428-0.018 * \mathrm{RSBI}+1.743 * \mathrm{LY}-0.419 * \mathrm{LSX}+\xi_{3, t+1}$

(4) Interest Rate Parity (IRP):

$\mathrm{RSBI}-\mathrm{RLIB}=8.600+\xi_{4, t+1}$

Dapat dikemukakan bahwa koefisien negatif dari unsur trend pada persamaan (1) menunjukkan bahwa dalam jangka panjang perilaku nilai tukar rupiah cenderung depresiatif terhadap US\$. Dari persamaan (2) diperlihatkan bahwa dalam jangka panjang, perkembangan harga dan output secara signifikan mempengaruhi penciptaan kesempatan kerja; sementara pengaruh suku bunga, walaupun secara teoritis mempunyai arah benar (negatif), namun tidak begitu signifikan secara statistik. Kecenderungan penurunan kesempatan kerja dalam jangka panjang tidak terlalu signifikan. Sementara itu, dalam jangka panjang perilaku real money 
balance (M0) pada persamaan (3) secara signifikan tergantung pada perkembangan output riil dan pasar modal; sementara suku bunga berpengaruh tidak terlalu signifikan. Yang terakhir, persamaan (4) menunjukkan bahwa dalam jangka panjang perilaku interest rate differential relatif konstan

\section{Tabel IV.3.4.a.}

\section{Hasil Penaksiran Model dengan Exactly Identifying Restriction}

ML estimates subject to exactly identifying restriction(s)

Estimates of Restricted Cointegrating Relations (SE's in Brackets)

Converged after 2 iterations

Cointegration with unrestricted intercepts and restricted trends in the VAR

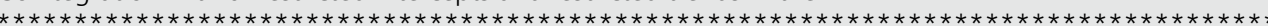

94 observations from 1980Q3 to 2003Q4. Order of VAR $=2$, chosen $r=4$.

List of variables included in the cointegrating vector:

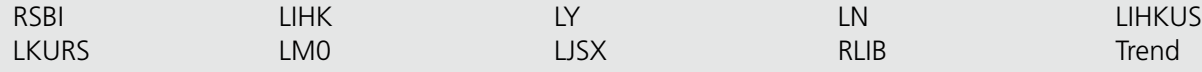

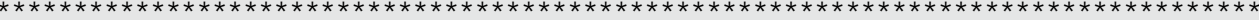

List of imposed restriction(s) on cointegrating vectors:

$a 2=1 ; a 5=-1 ; a 6=-1 ; a 9=0 ; b 4=1 ; b 5=0 ; b 8=0 ; b 9=0 ; c 4=0 ; c 5=0 ; c 7=1 ; c 9=0 ; d 1=1 ; d 2=0 ; d 3=0 ; d 9=-1$.

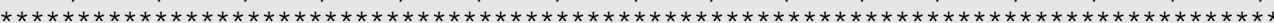

Vector 1

Vector 2

Vector 3

Vector 4

$\begin{array}{ll}.052411 & -.0068396\end{array}$

$-.032466$

1.0000

(.027227)

$(.0045331)$

(.018531)

$\left({ }^{*}\right.$ NONE*)

LIHK

1.0000
$*$ NONE* $^{*}$

$-1.2129$

$-3.1576$

0.00

LY

.10158

( .33961)

( .75245)

$\left({ }^{*} N O N E *\right)$

LY

( 2.7884$)$

$-1.0009$

$-2.2793$

0.00

LN

7.7144

( .39471)

( 1.5463$)$

( *NONE*)

( 9.0811$)$

1.0000

$-.0000$

166.3470

LIHKUS

$-1.0000$

$\left({ }^{*}\right.$ NONE $\left.^{*}\right)$

$\left({ }^{*} \mathrm{NONE}^{*}\right)$

(142.6221)

( ${ }^{*}$ NONE $\left.^{*}\right)$

0.00

0.00

4.1131

LKURS

$-1.0000$

( *NONE*)

$\left({ }^{*}\right.$ NONE*)

(205.0157)

$\left({ }^{*} \mathrm{NONE}^{*}\right)$

.070137

( . .10970)

.50661

$-20.4136$

LMO

$-1.2448$

.27365

( . .45110)

( 14.8878)

( 1.2730$)$

( . 10145)

1.0000

$-5.3090$

LJSX $\quad-.92696$

0.00

( $\left.{ }^{*} \mathrm{NONE}^{\star}\right)$

( 27.0969)

( 1.0334$)$

$\left({ }^{*} \mathrm{NONE}^{*}\right)$

.29105

$-16.2673$

RLIB $\quad 0.00$

$\left({ }^{*} \mathrm{NONE}^{*}\right)$

0.00

( .11891)

( 18.5039)

RLIB

.065925

$\left({ }^{*}\right.$ NONE*)

0.00

$-1.0000$

Trend

.024107

$\left({ }^{*} N O N E^{*}\right)$

$\left({ }^{*} \mathrm{NONE}^{*}\right)$

$(.045967)$

$(.0096146)$

.037375

63086

$(.035585)$

( 1.9941$)$

LL subject to exactly identifying restrictions $=1248.6$

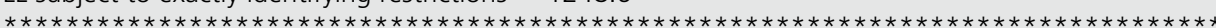


Tabel IV.3.4.b.

Hasil Penaksiran Model dengan Over Identifying Restriction

ML estimates subject to over identifying restriction(s)

Estimates of Restricted Cointegrating Relations (SE's in Brackets)

Converged after 8 iterations

Cointegration with unrestricted intercepts and restricted trends in the VAR

94 observations from 1980Q3 to 2003Q4. Order of VAR $=2$, chosen $r=4$.

List of variables included in the cointegrating vector:

$\begin{array}{lllll}\text { RSBI } & \text { LIHK } & \text { LY } & \text { LN } & \text { LIHKUS } \\ \text { LKURS } & \text { LMO } & \text { LSX } & \text { RLIB } & \text { Trend } \\ * * * * * * * * * * * * * * * * * * * * * * * * * * * * * * * * * * * * * * * * * * * * * * * * * * * * * * * * * * * * * * * * * * * * * * * * * * * * *\end{array}$

List of imposed restriction(s) on cointegrating vectors:

$a 2=1 ; a 5=-1 ; a 6=-1 ; a 9=0 ; \quad b 4=1 ; b 5=0 ; b 8=0 ; b 9=0 ; \quad c 4=0 ; c 5=0 ; c 7=1 ; c 9=0 ; d 1=1 ; d 2=0 ; d 3=0 ;$ $d 9=-1 ; a 1=0 ; a 3=0 ; a 4=0 ; a 7=0 ; a 8=0 ; b 3=0 ; b 6=0 ; b 7=0 ; c 2=-1 ; c 6=0 ; c 10=0 ; d 4=0 ; d 5=0 ; d 6=0$; $d 7=0 ; d 8=0 ; d 10=0 ;$

\begin{tabular}{|c|c|c|c|c|}
\hline $\mathrm{RSBI}$ & $\begin{array}{c}\text { Vector } 1 \\
-.0000 \\
\left({ }^{*} \text { NONE* }^{*}\right)\end{array}$ & $\begin{array}{r}\text { Vector } 2 \\
.01878 \\
(.02092)\end{array}$ & $\begin{array}{r}\text { Vector } 3 \\
.017855 \\
(.022261)\end{array}$ & $\begin{array}{r}\text { Vector } 4 \\
1.0000 \\
\left({ }^{*} \text { NONE* }^{*}\right)\end{array}$ \\
\hline LIHK & $\begin{array}{l}1.0000 \\
\left({ }^{*} \mathrm{NONE}^{*}\right)\end{array}$ & $\begin{array}{r}-.22036 \\
(-.07110)\end{array}$ & $\begin{array}{r}-1.0000 \\
\left({ }^{*} N O N E *\right)\end{array}$ & $\begin{array}{r}-.0000 \\
\left({ }^{*} \text { NONE* }^{*}\right)\end{array}$ \\
\hline LY & $\begin{array}{l}.0000-.29982 \\
\left({ }^{*} N O N{ }^{*}\right)\end{array}$ & $\begin{array}{r}-1.7433 \\
(-.09401)\end{array}$ & $\begin{array}{r}.0000 \\
(-.6801)\end{array}$ & $\left({ }^{*} \mathrm{NONE}^{*}\right)$ \\
\hline LN & $\begin{array}{l}-.0000 \\
\left({ }^{*} \mathrm{NONE}^{*}\right)\end{array}$ & $\begin{array}{r}1.0000 \\
\left(\quad{ }^{*} \text { NONE* }^{*}\right)\end{array}$ & $\begin{array}{r}-.0000 \\
\left(\quad{ }^{*} \mathrm{NONE}^{*}\right)\end{array}$ & $\begin{array}{r}-.0000 \\
\left(\quad{ }^{*} \text { NONE* }^{*}\right)\end{array}$ \\
\hline LIHKUS & $\begin{array}{c}-1.0000 \\
\left({ }^{*} \mathrm{NONE}^{*}\right)\end{array}$ & $\begin{array}{r}.0000 \\
\left(\quad{ }^{*} \text { NONE* }^{*}\right)\end{array}$ & $\begin{array}{r}-.0000 \\
\left(\quad{ }^{*} \mathrm{NONE}^{*}\right)\end{array}$ & $\begin{array}{r}.0000 \\
\left({ }^{*} \text { NONE }^{*}\right)\end{array}$ \\
\hline LKURS & $\begin{array}{c}-1.0000 \\
\left(\quad *{ }^{N O N E *}\right)\end{array}$ & $\begin{array}{r}-.0000 \\
\left(\quad{ }^{*} \mathrm{NONE}^{*}\right)\end{array}$ & $\begin{array}{r}.0000 \\
\left(\quad{ }^{*} \mathrm{NONE}^{*}\right)\end{array}$ & $\begin{array}{r}-.0000 \\
\left({ }^{*} \text { NONE }^{*}\right)\end{array}$ \\
\hline LMO & $\left(\begin{array}{l}-.0000 \\
\left({ }^{*} \mathrm{NONE}^{*}\right)\end{array}\right.$ & $\begin{array}{r}.0000 \\
\left(\quad{ }^{*} N^{\prime} N^{*}\right)\end{array}$ & $\begin{array}{r}1.0000 \\
\left(\quad * \text { NONE* }^{*}\right)\end{array}$ & $\left(\begin{array}{r}-.0000 \\
(\quad \text { NONE* }\end{array}\right.$ \\
\hline LSX & $\begin{array}{l}-.0000 \\
\left({ }^{*} \mathrm{NONE}^{*}\right)\end{array}$ & $\begin{array}{r}.0000 \\
\left(\quad{ }^{*} N^{\prime} O N E^{*}\right)\end{array}$ & $\begin{array}{r}.41932 \\
(.10131)\end{array}$ & $\left(\begin{array}{r}-.0000 \\
\left.\quad * \mathrm{NONE}^{*}\right)\end{array}\right.$ \\
\hline RLIB & $\begin{array}{r}-.0000 \\
\left(\quad{ }^{*} \mathrm{NONE}^{*}\right)\end{array}$ & $\begin{array}{r}.0000 \\
\left(\quad{ }^{*} \mathrm{NONE}^{*}\right)\end{array}$ & $\begin{array}{r}.0000 \\
\left(\quad{ }^{*} \mathrm{NONE}^{*}\right)\end{array}$ & $\begin{array}{r}-1.0000 \\
\left({ }^{*} \text { NONE }^{*}\right)\end{array}$ \\
\hline Trend & $\begin{array}{l}.0086897 \\
(.0048128)\end{array}$ & $\begin{array}{r}.7265 \mathrm{E}-3 \\
(.0072324)\end{array}$ & $\begin{array}{r}-.0000 \\
(\quad * N O N E *)\end{array}$ & $\begin{array}{r}.0000 \\
\left({ }^{*} \text { NONE }^{*}\right)\end{array}$ \\
\hline
\end{tabular}

LR Test of Restrictions CHSQ(17) $=32.3441[.016]$

$\mathrm{DF}=$ Total no of restrictions(33) - no of just-identifying restrictions(16)

LL subject to exactly identifying restrictions $=1248.6$

LL subject to over-identifying restrictions $=1232.4$ 


\section{III.1.4 Penaksiran (Reduced Form) Vector Error Correcting Model (VECM)}

Setelah melakukan penaksiran model kointegrasi sistem permodelan VAR, langkah terakhir yang dilakukan adalah penaksiran model (Reduced Form) Vector Error Correcting Model (VECM). Hasil penaksiran model memberikan hasil yang pada umumnya yang cukup baik, yang tercermin pada beberapa kriteria, antara lain: [Tabel IV.3.5]

Tabel IV.3.5.

Hasil Penaksiran Model (Reduced Form) Vector Error Correcting Model (VECM)

\begin{tabular}{|c|c|c|c|c|}
\hline Var. Dependen & $\mathbf{R}^{2}$ & \multicolumn{2}{|c|}{ ECM Terms } & Perilaku Kestabilan (CUSUM test) \\
\hline $\mathrm{D}(\mathrm{RSBI})$ & 0.74 & $\begin{array}{l}\text { PPP } \\
\text { EDE } \\
\text { MME } \\
\text { IRP }\end{array}$ & $\begin{array}{l}(-), * * \\
(+) \\
(-) \\
(-), * * *\end{array}$ & $\begin{array}{l}\text { Kecenderungan ke arah ketidakstabilan terlihat } \\
\text { pada periode pasca krisis ekonomi 1997, tapi } \\
\text { masih dalam batas kisaran kestabilan. }\end{array}$ \\
\hline $\mathrm{D}(\mathrm{LIHK})$ & 0.64 & $\begin{array}{l}\text { PPP } \\
\text { EDE } \\
\text { MME } \\
\text { IRP }\end{array}$ & $\begin{array}{l}(+) \\
(-) \\
(+), * /- \\
(+), * /-\end{array}$ & $\begin{array}{l}\text { Walaupun masih dalam batas kisaran kestabilan, } \\
\text { perilaku persamaan cender-ung rentan terhadap } \\
\text { gejolak ekonomi. }\end{array}$ \\
\hline $\mathrm{D}(\mathrm{LY})$ & 0.33 & $\begin{array}{l}\text { PPP } \\
\text { EDE } \\
\text { MME } \\
\text { IRP }\end{array}$ & $\begin{array}{l}(+) \\
(-), * * \\
(+), * \\
(+)\end{array}$ & $\begin{array}{l}\text { Walaupun masih dalam batas kisaran kestabilan, } \\
\text { perilaku persamaan cender-ung rentan terhadap } \\
\text { gejolak ekonomi. }\end{array}$ \\
\hline$D(N)$ & 0.51 & $\begin{array}{l}\text { PPP } \\
\text { EDE } \\
\text { MME } \\
\text { IRP }\end{array}$ & $\begin{array}{l}(-) \\
(-), * * \\
(+), * * \\
(+), * /-\end{array}$ & $\begin{array}{l}\text { Walaupun masih dalam batas kisaran kestabilan, } \\
\text { perilaku persamaan cender-ung rentan terhadap } \\
\text { gejolak ekonomi. }\end{array}$ \\
\hline D(LIHKUS) & 0.57 & $\begin{array}{l}\text { PPP } \\
\text { EDE } \\
\text { MME } \\
\text { IRP }\end{array}$ & $\begin{array}{l}(-) \\
(-), * * * \\
(+), * * \\
(+)\end{array}$ & - \\
\hline $\mathrm{D}(\mathrm{LKURS})$ & 0.25 & $\begin{array}{l}\text { PPP } \\
\text { EDE } \\
\text { MME } \\
\text { IRP }\end{array}$ & $\begin{array}{l}(+), * /- \\
(-) \\
(+) \\
(+)\end{array}$ & $\begin{array}{l}\text { Sangat stabil sebelum 1997, dan cenderung } \\
\text { bergejolak pada periode pasca krisis ekonomi } \\
1997 .\end{array}$ \\
\hline $\mathrm{D}(\mathrm{LMO})$ & 0.18 & $\begin{array}{l}\text { PPP } \\
\text { EDE } \\
\text { MME } \\
\text { IRP }\end{array}$ & $\begin{array}{l}(+), * /- \\
(+) \\
(-) \\
(-)\end{array}$ & $\begin{array}{l}\text { Kecenderungan ke arah ketidakstabilan terlihat } \\
\text { sejak awal 1990-an (fenomena tingginya capital } \\
\text { inflow), tapi masih dalam batas kisaran kestabilan. }\end{array}$ \\
\hline$D($ LSX) & 0.25 & $\begin{array}{l}\text { PPP } \\
\text { EDE } \\
\text { MME } \\
\text { IRP }\end{array}$ & $\begin{array}{l}(-) \\
(+), * /- \\
(-), * * \\
(-)\end{array}$ & $\begin{array}{l}\text { Kecenderungan ke arah ketidakstabilan terlihat } \\
\text { sejak awal 1990-an (fenomena tingginya capital } \\
\text { inflow), tapi masih dalam batas kisaran kestabilan. }\end{array}$ \\
\hline$D(R L I B)$ & 0.13 & $\begin{array}{l}\text { PPP } \\
\text { EDE } \\
\text { MME } \\
\text { IRP }\end{array}$ & $\begin{array}{l}(-) \\
(-), \\
(+) \\
(+)\end{array}$ & - \\
\hline
\end{tabular}


(i) goodness of fit (koefisien determinasi, $R^{2}$ ) yang cukup tinggi untuk konteks regresi antar variabel dalam bentuk first difference. $\mathrm{R}^{2}$ persamaan suku bunga SBI merupakan yang tertinggi (0.74), sementara suku bunga LIBOR merupakan yang terendah (0.13).

(ii) Adanya respons (penyesuaian) dinamis perkembangan jangka pendek masing-masing variabel terhadap kondisi keseimbangan jangka panjang (error correcting term) dalam sistem. Hal tersebut tercermin pada signifikasi parameter error correcting term pada tingkat signifikasi yang pada umumnya cukup tinggi. Sebagian besar variabel secara signifikan merespons 2 kondisi keseimbangan, sementara yang lainnya merespons 1 atau bahkan 3 kondisi keseimbangan.

(iii) Hasil uji stabilitas parameter berdasarkan cummulative sum recursive residuals (CUSUM test) menujukkan bahwa secara umum persamaan cukup stabil, walaupun beberapa di antaranya mempunyai kecenderungan ke arah perkembangan yang tidak stabil, terutama pada periode pasca fenomena tingginya capital inflow pada awal 1990 dan pasca krisis ekonomi 1997.

Selanjutnya, dari penaksiran matrik covarians dari residual (System Covariance Matrix of Errors) juga disimpulkan bahwa tidak ada keterkaitan yang signifikan antar-residual dalam sistem. Sementara itu, Error Corecting Terms diformulasikan sebagai berikut:

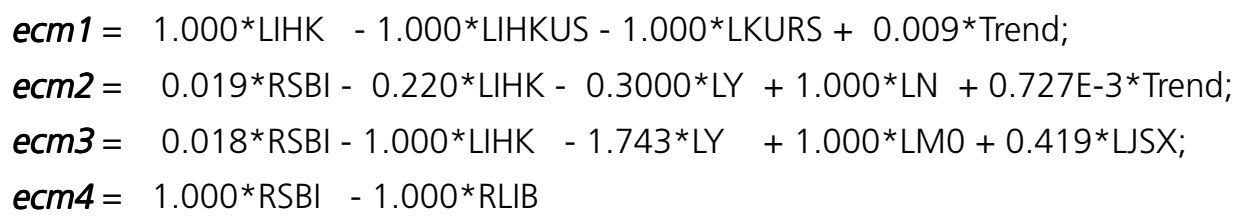

\section{III.1.5 Persistence Profiles}

Dengan berdasarkan parameter struktural dari tahap penaksiran pada bagian sebelumnya, maka tahapan awal dalam mengamati keterkaitan antar variabel dalam sistem permodelan analisis fungsi 'generalized' impulse responseyang terkait dengan penaksiran persistence profiles, yang ditujukan untuk menangkap pengaruh shocks terhadap 4 keterkaitan keseimbangan jangka panjang antar variabel dalam sistem. Dalam kaitan ini, akan dilihat sejauhmana kecepatan penyesuaian untuk kembali kepada keseimbangan apabila terjadi shocks yang menyebabkan deviasi perilaku keseimbangan tersebut. Profil tersebut dibangun dengan restriksi dimana pada saat horison waktu menuju infinity, deviasi terhadap keseimbangan menjadi nol. Persistence profiles (PP) akan diamati berdasarkan sumber shocks, apakah shocks yang terjadi pada sistem secara keseluruhan (system-wide shocks) atau shocks yang terjadi secara parsial pada suatu variabel. 
Dari analisis pengaruh shocks secara keseluruhan, dapat dilihat bahwa keterkaitan jangka panjang PPP (CV1) relatif paling stabil di antara keterkaitan jangka panjang lainnya, dimana deviasi yang terjadi tidak terlalu besar dan menurun secara konsisten dan cepat. Dalam kaitan ini $80 \%$ penyesuaian terjadi pada 4 atau 5 kuartal dan penyesuaian yang komplit terjadi sekitar 2 tahun. Sebaliknya, keterkaitan jangka panjang EDE (CV2) relatif paling rentan, dimana shocks menyebabkan sangat besarnya deviasi keseimbangan dan sangat lamanya terjadinya penyesuaian yang komplit (>10 tahun).[Grafik IV.3.3]
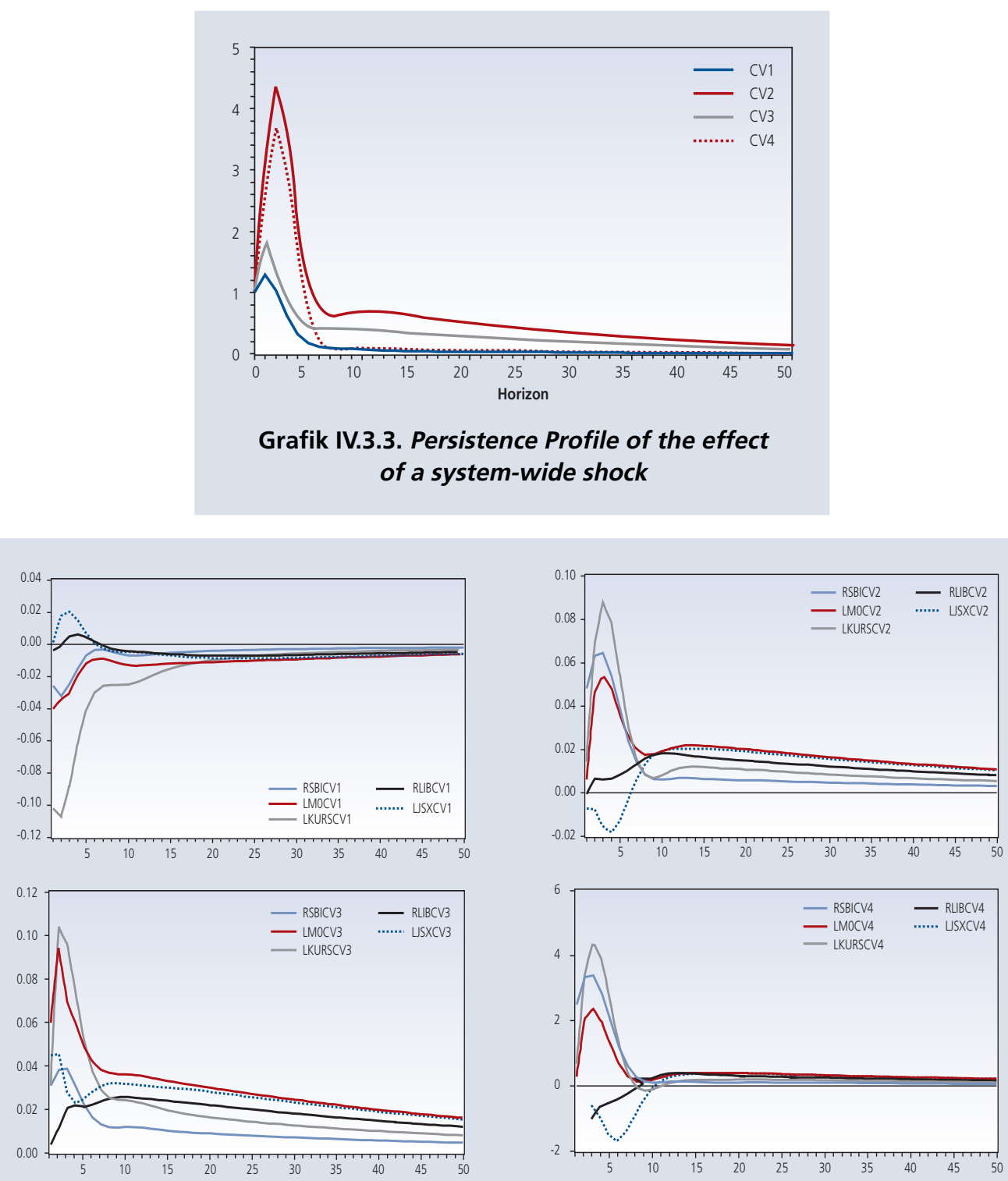

Grafik IV.3.4. Persistence Profile of the effect of a particular variable shock 
Sementara itu, analisis pengaruh shocks secara parsial yang diperhitungkan bersumber dari perilaku variabel-variabel 'eksogen', yaitu suku bunga dalam negeri (RSBI), uang primer (LMO), kurs (LKURS), suku bunga luar negeri (RLIB), dan indeks saham (LJSX). Profil deviasi dari masing-masing kondisi keseimbangan adalah CV1(PPP), CV2(EDE), CV3(MME), dan CV4(IRP). Pengamatan ditujukan untuk melihat peranan shocks yang bersumber dari perilaku masing-masing variabel 'eksogen' pada masing-masing kondisi keseimbangan. Dari analisis teresebut disimpulkan bahwa pada proses penyesuaian $1-2$ tahun pertama, pengaruh shocks yang mendorong deviasi terbesar bersumber pada perilaku nilai tukar (LKURS), kemudian disusul oleh uang primer (LMO) dan suku bunga (RSBI). Selanjutnya, pengaruh shocksyang bersumber dari perilaku uang primer menyebabkan proses penyesuaian (komplit) berjalan relatif paling lama dibandingkan dengan pengaruh shocks yang bersumber dari perilaku variabel-variabel lain. [Grafik IV.3.4]

\subsection{Analisis Kebijakan Moneter: Sekilas mengenai Keterkaitan antar Variabel dan Panjang Lag Kebijakan Moneter}

Dengan berdasarkan parameter struktural dari tahap penaksiran yang disampaikan sebelumnya, tahapan berikutnya adalah analisis yang terkait dengan penaksiran fungsi 'generalized' impulse response dan pengidentifikasian keterkaitan antara variabel sasaran operasional dan sasaran akhir kebijakan, serta pengidentifikasian panjang lag kebijakan moneter. Seperti telah disinggung pada bagian pembuka, keterkaitan antar-variabel dan panjang lag kebijakan moneter diamati melalui analisis fungsi impuls respons (impulse respons function) dan dekomposisi varians (variance decomposition), dengan identifikasi keterkaitan inovasi fungsional yang mengacu pada kondisi umum (generalized), bukan ortogonalitas (orthogonality). Dengan tidak mengurangi makna keterkaitan antar masingmasing variabel secara keseluruhan dalam sistem permodelan, sesuai dengan tujuan penelitian, bagian ini menekankan beberapa keterkaitan utama yang relevan dengan tujuan penulisan.

Dengan demikian, bagian ini akan difokuskan pada pengidentifikasian keterkaitan antara sasaran operasional kebijakan moneter, suku bunga SBI (SBI) dan uang primer (M0) dengan sasaran akhir kebijakan moneter, perkembangan output (Y), inflasi (IHK), dan kesempatan kerja (N). Adapun pengaruh variabel eksogen utama seperti nilai tukar (KURS), suku bunga luar negeri (RLIB), dan indeks harga saham (JSX) juga akan disampaikan, terkait dengan relevansi keberadaannya dalam sistem ekonomi. 


\section{III.2.1 Keterkaitan Utama}

Dari plot impuls respons yang disampaikan pada Grafik IV.3.5 dan Garfik IV.3.6, dapat ditarik beberapa kesimpulan utama, yaitu sebagai berikut.

(i) Suku bunga berpengaruh negatif pada pertumbuhan ekonomi, relatif netral pada kesempatan kerja, dan positif pada inflasi. Hasil ini terkait dengan inflation expectation formation (sisi penawaran) dan akumulasi peningkatan uang primer sebagai akibat pembayaran pokok dan bunga SBI yang terjual pada periode sebelumnya (sisi permintaan). Pengaruh ke inflasi tersebut lebih bersifat langsung. Jalur pengaruh lain dari sisi demand melalui pengaruh kenaikan suku bunga pada M0-real money balance (yang negatif: 3 - 6 kuartal), dan selanjutnya pengaruh MO pada pada aggregate demand dan inflasi (yang positif: 3-6 kuartal). Dengan demikian, kenaikan suku bunga akan menekan mendorong ekspektasi inflasi di sisi supply dan menekan inflasi di sisi demand.

(ii) Ekspansi uang primer berpengaruh positif pada ouput (hanya dalam jangka pendek, tidak dalam jangka panjang), serta senantiasa positif pada harga dan employment. Pengaruh dengan jalur tidak langsung dapat dijelaskan melalui pengaruh peningkatan M0 pada suku bunga (yang positif dalam jangka sangat pendek dan selanjutnya negatif), serta selanjutnya pengaruh suku bunga ke output (yang positif dalam jangka pendek) dan inflasi (yang positif)

(iii) Perilaku pengaruh kedua policy variables (suku bunga SBI dan uang primer) pada indikator sasaran akhir kebijakan (output, harga, dan kesempatan kerja) cenderung "serupa". Hal ini tidak terlepas dari masih cukup berperannya kedua policy variables tersebut dalam operasional pengendalian moneter, dimana pengaruhnya cenderung bersifat komplemen. Seperti yang dijelaskan dalam pemaparan empiris sebelumnya, pada periode pasca krisis, perilaku kedua indikator tersebut saling merespon. Dalam kaitan ini, dari uji kausalitas

\begin{tabular}{|l|c|c|c|}
\hline \multicolumn{3}{|c|}{ Tabel IV.3.6. } \\
Hasil Uji Kausalitas \\
\hline Pairwise Granger Causality Tests (Lags: 4) & Obs & F-Statistic & Probability \\
Null Hypothesis: (Final Target Y) & 46 & 111.733 & 0.000 \\
M0 does not Granger Cause SBI & & 1801.67 & 0.000 \\
SBI does not Granger Cause M0 & Obs & F-Statistic & Probability \\
Null Hypothesis: (Final Target IHK) & 46 & 19626.9 & 0.000 \\
M0 does not Granger Cause SBI & & 2505.60 & 0.000 \\
SBI does not Granger Cause M0 & Obs & F-Statistic & Probability \\
Null Hypothesis: (Final Target N) & 46 & 2566.47 & 0.000 \\
M0 does not Granger Cause SBI & & 681.069 & 0.000 \\
SBI does not Granger Cause M0 & & &
\end{tabular}


pengaruh policy variables pada indikator sasaran akhir output, dapat dilihat bahwa respons kenaikan suku bunga pada saat terjadinya "excess liquidity" relatif kuat dibandingkan dengan peningkatan jumlah besaran moneter pada saat terjadi kontraksi moneter yang berlebihan melalui peningkatan suku bunga. Sementara itu, dengan menggunakan indikator sasaran akhir harga, yang terjadi adalah sebaliknya.

(iv) Perkembangan nilai tukar yang melemah (depresiatif) berpengaruh negatif pada perkembangan output, positif pada inflasi, serta relatif netral pada perkembangan kesempatan kerja. Sementara itu, peningkatan suku bunga luar negeri dalam jangka pendek berpengaruh positif pada perkembangan output, tetapi berpengaruh negatif dalam jangka panjang. Pengaruh peningkatan suku bunga tersebut adalah positif pada inflasi dan negatif pada perkembangan kesempatan kerja. Yang terakhir, Perkembangan indeks harga saham secara keseluruhan positif pada perkembangan output dan kesempatan kerja, sementara pengaruhnya pada inflasi adalah negatif dalam jangka pendek dan positif dalam jangka panjang.

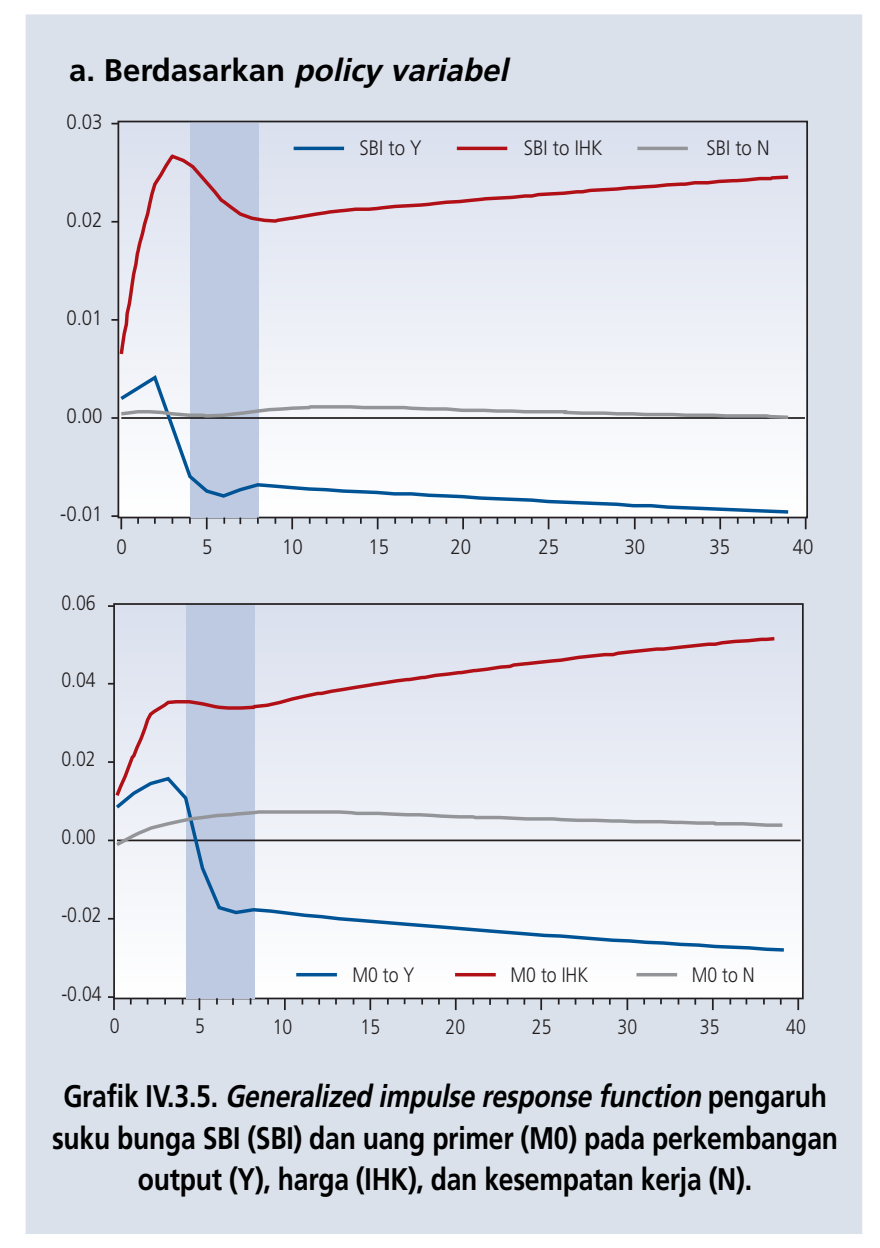




\section{b. Berdasarkan sasaran akhir kebijakan}
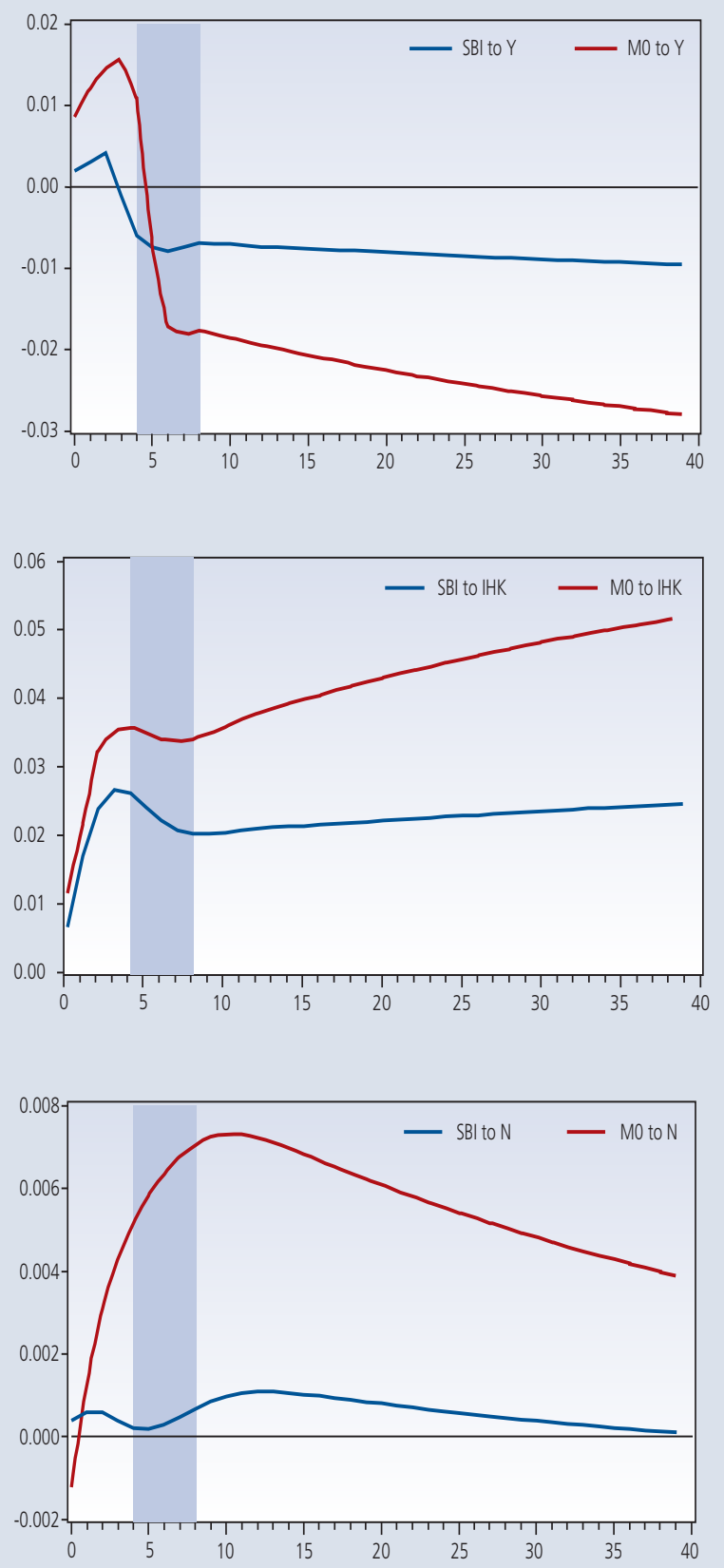

Grafik IV.3.5. Generalized impulse response function pengaruh suku bunga SBI (SBI) dan uang primer (M0) pada perkembangan output (Y), harga (IHK), dan kesempatan kerja (N). 


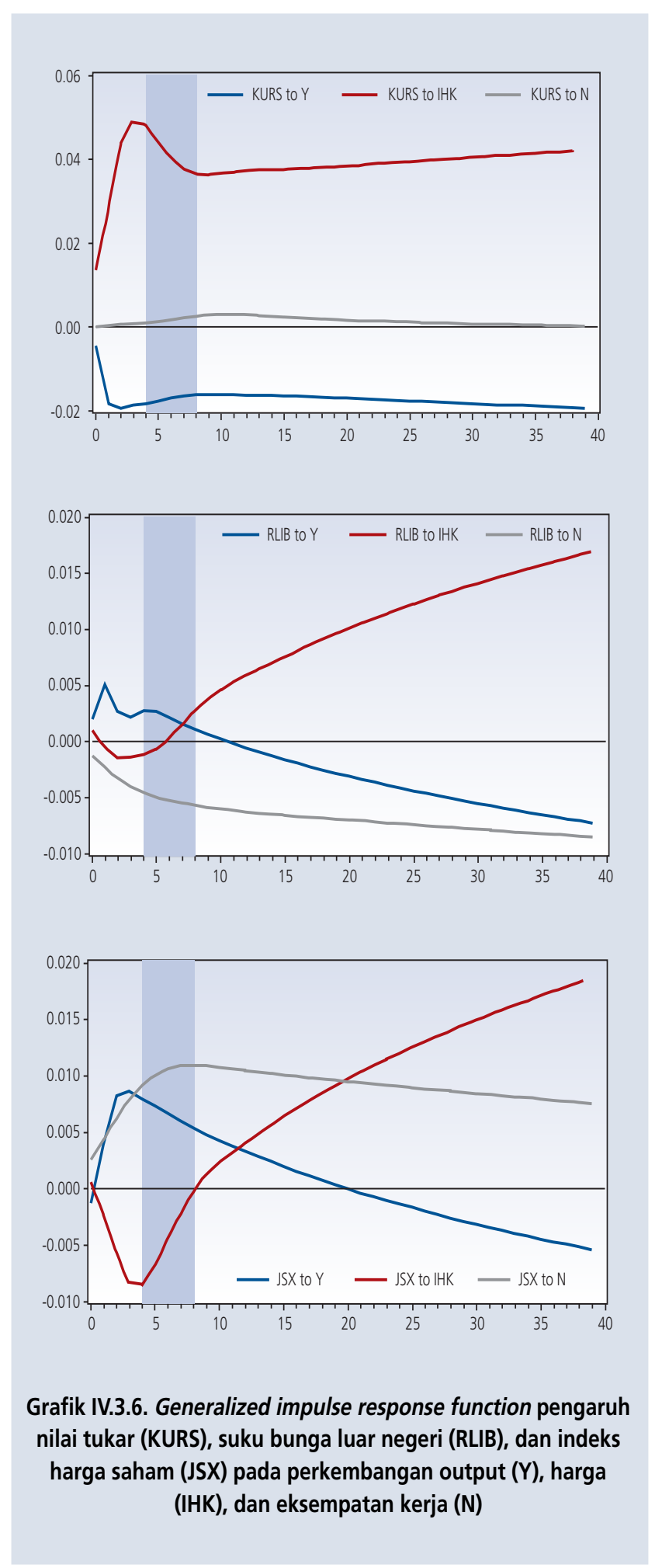




\section{III.2.2 Dekomposisi kontribusi pengaruh variabel}

Dari analisis dekomposisi varians disimpulkan bahwa policy variables (suku bunga SBI dan uang primer) berpengaruh secara signifikan dan persisten hanya hanya pada inflasi (kontribusi suku bunga sekitar 20 - 34\%, sementara uang primer sekitar 30\%). Pengaruh policy variables tersebut pada pertumbuhan output dan kesempatan kerja relatif kecil. Nilai

\begin{tabular}{|c|c|c|c|c|c|c|c|c|c|}
\hline Horizon & SBI & IHK & Y & $N$ & Horizon & KURS & IHK & Y & N \\
\hline 0 & 1.00 & 0.09 & 0.00 & 0.00 & 0 & 1.00 & 0.39 & 0.02 & 0.00 \\
\hline 1 & 0.67 & 0.34 & 0.03 & 0.00 & 1 & 0.95 & 0.29 & 0.04 & 0.00 \\
\hline 2 & 0.53 & 0.32 & 0.04 & 0.00 & 2 & 0.91 & 0.24 & 0.04 & 0.00 \\
\hline 3 & 0.48 & 0.29 & 0.03 & 0.00 & 3 & 0.89 & 0.22 & 0.04 & 0.00 \\
\hline 4 & 0.45 & 0.26 & 0.03 & 0.00 & 4 & 0.87 & 0.21 & 0.04 & 0.00 \\
\hline 5 & 0.44 & 0.25 & 0.03 & 0.00 & 5 & 0.86 & 0.20 & 0.04 & 0.00 \\
\hline 10 & 0.40 & 0.22 & 0.03 & 0.01 & 10 & 0.84 & 0.24 & 0.05 & 0.01 \\
\hline 20 & 0.34 & 0.20 & 0.02 & 0.01 & 20 & 0.74 & 0.32 & 0.08 & 0.02 \\
\hline 30 & 0.30 & 0.19 & 0.02 & 0.01 & 30 & 0.63 & 0.36 & 0.09 & 0.04 \\
\hline 40 & 0.28 & 0.18 & 0.02 & 0.01 & 40 & 0.55 & 0.39 & 0.10 & 0.05 \\
\hline Horizon & Mo & IHK & Y & N & Horizon & RLIB & IHK & Y & N \\
\hline 0 & 1.00 & 0.29 & 0.08 & 0.02 & 0 & 1.00 & 0.00 & 0.00 & 0.02 \\
\hline 1 & 0.95 & 0.31 & 0.04 & 0.02 & 1 & 0.96 & 0.01 & 0.00 & 0.01 \\
\hline 2 & 0.94 & 0.31 & 0.04 & 0.02 & 2 & 0.93 & 0.02 & 0.00 & 0.01 \\
\hline 3 & 0.94 & 0.31 & 0.03 & 0.02 & 3 & 0.92 & 0.02 & 0.00 & 0.01 \\
\hline 4 & 0.94 & 0.31 & 0.03 & 0.02 & 4 & 0.91 & 0.02 & 0.01 & 0.01 \\
\hline 5 & 0.94 & 0.31 & 0.03 & 0.02 & 5 & 0.90 & 0.02 & 0.01 & 0.01 \\
\hline 10 & 0.90 & 0.31 & 0.03 & 0.01 & 10 & 0.88 & 0.04 & 0.01 & 0.03 \\
\hline 20 & 0.81 & 0.30 & 0.02 & 0.01 & 20 & 0.87 & 0.05 & 0.01 & 0.05 \\
\hline 30 & 0.75 & 0.29 & 0.02 & 0.01 & 30 & 0.87 & 0.04 & 0.01 & 0.08 \\
\hline 40 & 0.72 & 0.29 & 0.02 & 0.01 & 40 & 0.87 & 0.04 & 0.01 & 0.11 \\
\hline Horizon & JSX & IHK & Y & $N$ & & & & & \\
\hline 0 & 1.00 & 0.00 & 0.00 & 0.07 & & & & & \\
\hline 1 & 0.97 & 0.00 & 0.00 & 0.06 & & & & & \\
\hline 2 & 0.93 & 0.00 & 0.00 & 0.07 & & & & & \\
\hline 3 & 0.90 & 0.00 & 0.01 & 0.08 & & & & & \\
\hline 4 & 0.88 & 0.00 & 0.01 & 0.09 & & & & & \\
\hline 5 & 0.86 & 0.00 & 0.02 & 0.10 & & & & & \\
\hline 10 & 0.73 & 0.00 & 0.04 & 0.14 & & & & & \\
\hline 20 & 0.48 & 0.03 & 0.08 & 0.12 & & & & & \\
\hline 30 & 0.32 & 0.05 & 0.11 & 0.08 & & & & & \\
\hline 40 & 0.22 & 0.08 & 0.12 & 0.06 & & & & & \\
\hline
\end{tabular}


tukar merupakan variabel eksogen yang sangat penting dalam mempengaruhi inflasi (20 $40 \%$ ). Pengaruhnya pada output mulai tampak dalam jangka menengah panjang. (tidak pada kesempatan kerja). Sementara itu, variabel eksogen lain (suku bunga luar negeri dan indek harga saham) relatif kecil.[Tabel IV.3.7]

\section{III.2.3 Panjang lag kebijakan moneter}

Dengan menggunakan instrumen kebijakan (policy variables) suku bunga SBI dan uang primer, panjang tenggat waktu (lag) pengaruh kebijakan moneter pada output (GDP) dan harga (IHK) diidentifikasi antara 1 tahun, dimana pengaruh mencapai the first extreeme (puncak) sampai dengan 2 tahun, dimana pengaruh mulai mengalami pola perkembangan yang persisten. Sementara itu, pengaruh pada kesempatan kerja cenderung hilang secara gradual pada periode setelah tahun ke-3. Dengan demikian, rata-rata panjang lag kebijakan moneter diidentifikasi sepanjang 1.5 tahun.

Hasil identifikasi panjang lag kebijakan moneter tersebut hasil pengamatan yang telah dilakukan sebelumnya. Hasil tersebut sekaligus memperkuat argumen mengenai semakin perlunya perumusan strategi kebijakan moneter secara forward looking dan dilakukan secara pre-emptive agar sasaran akhir kebijakan dapat dicapai dengan efektif. Permasalahan yang muncul adalah bahwa pengaruh kebijakan moneter tersebut terhadap kegiatan ekonomi rii dan inflasi, bekerja melalui berbagai saluran transmisi kebijakan moneter. Dengan demikian, sebagai pengayaan substansi analisi diperlukan pula pemahaman lebih lanjut yang jelas dan lengkap mengenai mekanisme transmisi kebijakan moneter di Indonesia. ${ }^{13}$

\section{CATATAN PENUTUP}

Pengembangan analisis kebijakan moneter yang sesuai untuk kasus Indonesia tentunya tidaklah mudah. Hal ini mengingat karakteristik perekonomian Indonesia cukup unik dan masih dalam proses transisi struktural dan kelembagaan yang cukup panjang, yang diwarnai dengan tingginya fluktuasi beberapa perkembangan variabel makro ekonomi. Penelitian ini mengetengahkan hal yang mendasar dalam merumuskan kerangka kebijakan yang optimal untuk kasus di Indonesia, yaitu pengembangan model hipotetis dalam bentuk model makro stuktural jangka panjang, Structural Cointegrating Vector Autoregression (VAR) yang efektif

13 Beberapa studi intensif mengenai mekanisme transmisi kebijakan moneter di Indonesia telah dilakukan oleh beberapa penulis. Dalam studi yang menggunakan pendekatan VAR tersebut, beberapa jalur transmisi kebijakan moneter dikaji, di antaranya jalur besaran moneter, suku bunga, kredit, nilai tukar, harga aset, dan ekspektasi inflasi. Untuk selengkapnya, lihat: Warjiyo, Perry dan Juda Agung, (Ed.) (2002), Transmission Mechanism of Monetary Policy in Indonesia, Bank Indonesia: Jakarta, Juli 2002. 
dalam menjelaskan beberapa isu terkait dengan tujuan penelitian. Hal ini dilandaskan pada pertimbangan kemampuan sistem permodelan dalam mengakomodir karakteristik dasar model dinamis keseimbangan umum jangka panjang dan menjelaskan respons kebijakan berdasarkan kaidah keoptimalan. Dari hasil penaksiran dan analisis model dapat disimpulkan bahwa secara umum pendekatan yang dikembangkan dapat menjelaskan perilaku kebijakan moneter di Indonesia dengan baik.

Perlu dikemukakan bahwa pendekatan yang digunakan dalam penelitian ini lebih ditujukan pada relevansi permasalahan yang diajukan serta asumsi yang mendasari, khususnya terkait dengan pengaruh kebijakan dan perkembangan di sektor-sektor lain (fiskal, nilai tukar, dan riil) yang berjalan seperti yang telah ditetapkan oleh Pemerintah dan Bank Indonesia. Dengan demikian, dengan adanya kendala keterbatasan dan pengolahan data (terutama data kesempatan kerja), potensi perubahan karakteristik perkembangan data, keunikan struktur perekonomian Indonesia, serta pergeseran orientasi kebijakan moneter, terutama pada masa terjadinya twin crises pada periode 1997.3 - 1999, sangat diperlukan suatu kehati-hatian dalam menginterpretasikan "magnitude" parameter permodelan.

Selain itu, juga disadari akan perlunya penggunaan kerangka pengkajian alternatif, atau bahkan pengembangan kerangka permodelan yang lebih realistis. Hal tersebut terutama terkait dengan fakta bahwa sebagai salah satu aspek strategis dalam bidang kajian kebijakan, perumusan kerangka kerja kebijakan moneter akan senantiasa menjadi suatu topik kajian yang layak untuk dicermati. Demikian pula, penelitian dengan hasil yang telah disampaikan di atas pada dasarnya juga dapat dianggap sebagai suatu penelitian awal. Dalam perspektif yang lebih luas, dalam penelitian ini belum dikaji secara tegas beberapa hal, antara lain terkait dengan konsistensi permodelan terkait dengan keberadaan 'economic puzzle', perumusan kerangka kebijakan moneter yang optimal, serta konsistensi dan kredibilitas kebijakan moneter. Berkaitan dengan penyusunan kerangka kebijakan moneter yang berlangsung saat ini, topik lanjutan tersebut tentunya merupakan suatu yang penting untuk dilakukan selanjutnya. 